\title{
Seagrass contribution to blue carbon in a shallow karstic coastal area of the Gulf of Mexico
}

\author{
Tania Cecilia Cota Lucero ${ }^{\text {Corresp., } 1}$, Jorge A. Herrera-Silveira ${ }^{\text {Corresp. } 1}$ \\ ${ }^{1}$ Marine Resources, Centro de Investigación y de Estudios Avanzados del Instituto Politécnico, Mérida, YUC, México \\ Corresponding Authors: Tania Cecilia Cota Lucero, Jorge A. Herrera-Silveira \\ Email address: tania.cota@cinvestav.mx, jorge.herrera@cinvestav.mx
}

Seagrass meadows provide multiple ecosystem services, including carbon sequestration. However, seagrass meadows are among the most threatened ecosystems worldwide. Determining the magnitude of the carbon stocks in seagrass meadows at the regional scale allows for the estimation of their global magnitude and identification of their importance in regional environmental mitigation strategies. The objective of the present study was to determine the structure of seagrass meadows in the Los Petenes Biosfera Reserve (LPBR) and evaluate their contributions to sinks of carbon in this system, located in Yucatan, which is considered the region with the largest seagrass extension in Mexico. Analyses of the seagrass meadows were executed following standardized protocols (spectral analysis, and isotope and carbon stock analyses). The LPBR stores an average of

2.2 $\pm 1.7 \mathrm{Mg} \mathrm{C}^{-1}$ in living biomass and $318 \pm 215 \mathrm{Mg} \mathrm{C}^{-1}$ in sediment (top $1 \mathrm{~m}$ ), and this carbon stock decreases with water depth. The seagrass community extends 149,613 ha, which represents the largest organic carbon stock (47 Tg C) documented in seagrass meadows in Mexico. Macroalgae and seagrass represent $76 \%$ of the organic carbon stored in sediment. If LPBR seagrass meadows are lost due to natural or anthropogenic impacts, $173 \mathrm{Tg} \mathrm{CO}_{2 \text { eq }}$ emissions could be released, which corresponds to the emissions generated by fossil fuel combustion of $27 \%$ of the current Mexican population. This information emphasizes the importance of seagrass meadows as a carbon sink in the region and their contribution to climate change mitigation, thus allowing for the implementation of necessary conservation strategies. 
1 Seagrass contribution to blue carbon in a shallow karstic coastal area of the Gulf 2 of Mexico

4 Tania C. Cota-Lucero ${ }^{1}$ and Jorge A. Herrera-Silveira ${ }^{1}$

5

$6 \quad{ }^{1}$ Marine Resources, Centro de Investigación y de Estudios Avanzados del Instituto Politécnico, 7 Mérida, YUC, México

8 Corresponding Author:

9 Tania C. Cota Lucero ${ }^{1}$

10 Jorge A. Herrera Silveira ${ }^{1}$

11 Km. 6 Carretera Antigua a Progreso. Mérida, Yuc. 97310, Mexico

12 Email address: tania.cota@cinvestav.mx

13 jorge.herrera@.cinvestav.mx

\section{Abstract}

Seagrass meadows provide multiple ecosystem services, including carbon sequestration, and are among the most threatened ecosystems worldwide. Determining the magnitude of the carbon stocks in seagrass meadows at the regional scale allows for the estimation of their global magnitude and identification of their importance in regional environmental mitigation strategies; however, few studies have quantified carbon sequestration in subtropical seagrass. The objective of the present study was to determine the structure of seagrass meadows in the Los Petenes Biosfera Reserve (LPBR), located in Yucatan, and is considered the region with the largest seagrass extension in Mexico. Analyses of the seagrass meadows followed standardized protocols (spectral analysis, and isotope and carbon stock analyses) suggested that LPBR stored an average of $2.2 \pm 1.7 \mathrm{MgC} \mathrm{ha}^{-1}$ in living biomass and $318 \pm 215 \mathrm{Mg} \mathrm{C}^{-1}$ in the top $1 \mathrm{~m}$ of sediments. This carbon stock decreased with water depth. and represents the largest organic carbon stock ( $47 \mathrm{Tg} \mathrm{C})$ documented in seagrass meadows in Mexico. Macroalgae and seagrass represent $76 \%$ of the organic carbon stored in sediment. If LPBR seagrass meadows were lost $173 \mathrm{Tg} \mathrm{CO} \mathrm{CO}_{2 \mathrm{e}}$ emissions would be released, which corresponds to the emissions generated by fossil fuel combustion of $27 \%$ of the current Mexican population.

Key words Autochthonous, Blue carbon, Mangroves, Seagrasses

\section{Introduction}

Seagrasses provide numerous ecosystem services, such as serving as a habitat and refuge for a high diversity of species, retaining sediment and protecting the coastal zone, healthy seagrass meadows, improve water quality, and regulate the impacts of greenhouse gases, particularly $\mathrm{CO}_{2}$ 
42

43

44

45

46

47

48

49

50

51

52

53

54

55

56

57

58

59

60

61

62

63

64

65

66

67

68

69

70

71

72

73

74

75

76

77

78

79
41 (Hemminga \& Nieuwenhuize, 1990, Constanza et al., 2014;). Indeed, seagrasses are more
42 efficient than tropical forest in carbon sequestration (McLeod et al., 2011).

Half of the carbon buried in marine sediments is found in coastal blue carbon habitats combined (i.e., mangrove, salt marshes and seagrass) (Duarte et al. 2013). Seagrass have a larger distribution $\left(0.33 \times 10^{6} \mathrm{~km}^{2}\right)$ than salt marshes and mangroves, whose habitats are restricted to intertidal areas along the coast (Charpy-Roubaud \& Sournia, 1990; Duarte \& Cebrian, 1996; Short et al., 2007). Because of their wide distribution and high productivity, it is important to quantify the contribution of seagrass meadows to continent-scale carbon budgets (Duarte \& Chiscano, 1999; Laffoley \& Grimsditch, 2009; Nellemann et al., 2009).

Shoot density, leaf area, and the specific characteristics of seagrass species regulate carbon storage (Mazarrasa et al., 2018). The structural complexity of seagrasses is related to both the above- and belowground biomass and contributes to sediment retention processes by trapping particles accumulating in sediments for millennia in the form of organic carbon (Hendrix et al. 2008; McLeod et al. 2011; Duarte \& Krause-Jensen 2017). Carbon stored in seagrass sediments comes from both the detritus produced by the degradation of its biomass (leaves, rhizomes, and roots), considered autochthonous carbon (Agawin \& Duarte, 2002; Hendriks et al., 2008; Tanaya et al., 2018), and from allochthonous sources such as the contributions of river sediments (Signa et al., 2017; Maklin et al., 2019). The origin of the carbon in seagrass ecosystems differs at the regional level. In some areas the proportion of allochthonous carbon in seagrass meadows exceeds autochthonous carbon (Gacia et al., 2002; Bouillon et al., 2008); these differences indicate the degree of connectivity between seagrass meadows and other ecosystems.

Anthropogenic impacts threaten seagrasses worldwide and have caused the disappearance of these habitats (Orth et al., 2006; Waycott et al., 2009). These impacts must be monitored at the regional scale (Carmen et al., 2019), to improve: 1) estimates of carbon stocks and the contribution of seagrass to global carbon stocks (Serrano et al., 2014); 2) relate carbon sources and their ability to store organic carbon with the influence of groundwater; and 3) provide data on the contribution of autochthonous vs allochthonous materials in carbon stocks.

Few studies have quantified organic carbon in seagrass ecosystems in Mexico, or related habitat health and the structure of these meadows (Samper-Villarreal et al., 2016, Herrera Silveira et al., 2020). In this context, it is important to determine the carbon stocks both in seagrass biomass and sediments associated with these habitats, as well as their sources, the structural complexity of the seagrass, and the water quality. Here, we hypothesized that the seagrass carbon stocks and their contribution to sediments differ with water depth and that habitat-forming seagrass is the main source of the accumulated organic matter in associated sediments.

Peer) reviewing PDF | (2020:11:55341:2:0:NEW 15 Jul 2021) 
80 This may help improve carbon estimations on a global scale and the variables associated with

81

82

83

84

85

86

87 88

89

90

91

92

93

94

95

96

97

98

99

100

101

102

103

104

105

106

107

108

109

110

111

112

113

114

115

116

117

118

119 those stocks. The study area corresponds to the marine protected area of Los Petenes Biosphere Reserve (LPBR), in the Gulf of Mexico. This region, of 151, 200 ha (Perez-Espinoza et al., 2019), is one of the largest continuous extension of seagrass on the Mexican coast Therefore, the primary objective of the present study was to characterize the structural complexity of seagrass meadows and determine their relationship with the spatial distribution of organic carbon stocks along to environmental gradients related to water depth. A secondary objective was to identify the main sources of this carbon and the influences of environmental variables.

\section{Materials \& Methods}

\section{Study Area}

The LPBR, one of the largest marine reserves $(282,857 \mathrm{ha})$ in the southeast region of the Gulf of Mexico (Fig. 1). Mangroves and petenes (vegetation islands similar to hammock ecosystems in Florida, USA) cover $23 \%$ of the terrestrial surface. The coastal zone is estuarine (181,991 ha), showing a substrate enriched in carbonates due to the karst characteristics of the continental shelf in this region. The largest extension of seagrasses in Mexico is distributed in this protected area, and the community is composed of three species (Thalassia testudinum, Syringodium filiforme and Halodule wrightii) that have been recorded at depths of up to $5 \mathrm{~m}$. This community shares substrates with a large diversity of macroalgae (Mateo Cid et al., 2013). This region maintains strong coastal hydrological connectivity since its karst nature favors groundwater discharges to the coast, thus contributing to the supply of nutrients there (Grivel-Piña, 1992; CONAGUA, 2006). Along its $100 \mathrm{~km}$ coastline, there are only two communities of less than 1000 inhabitants each, so it is an area of low anthropic environmental impact. This region is an area of biological, ecological, and scientific importance as a result of its conservation and diversity (Corbalá et al., 2007).

\section{Water Quality}

We visited the LPBR in May, 2017 and 2018 under CONANP permission (F.OO.9. DRPYyCM/060/2021). Transects were established perpendicular to the coast traveling $\square 25 \mathrm{~km}$ considering a depth gradient of 1 to $5 \mathrm{~m}$ (Fig. 1). At sampling stations, physicochemical water quality data and seagrass samples were collected. Water depth was measured using a portable depth gauge (Hondex Ps-7); temperature, salinity, and dissolved oxygen (OD) were measured in situ using a YSI-2030 multiparameter probe at $50 \mathrm{~cm}$ depth intervals from the surface to the bottom. Incident light data (\%) were obtained using a LI-250A spherical sensor (LICOR) that collected measurements every $50 \mathrm{~cm}$ deep across the entire water column. Water samples were collected in the immediate vicinity of the seagrass meadows for dissolved inorganic nutrient analysis $(\mathrm{n}=79)$. The nutrients analyzed were nitrates + nitrites $\left(\mathrm{NO}_{3}{ }^{-}+\mathrm{NO}_{2}{ }^{-}\right)$, soluble reactive 
120 phosphate (SRP), ammonium $\left(\mathrm{NH}_{4}{ }^{+}\right.$), and soluble reactive silicate (SRSi). These analyses were

121

122

123

124

125

126

127

128

129

130

131

132

133

134

135

136

137

138

139

140

141

142

143

144

145

146

147

148

149

150

151

152

153

154

155

156

157

158

159

performed according to the standard methods described in Strickland and Parsons (1972). The concentration of chlorophyll-a (Chl-a) was also determined using the method of Parsons et al. (1984). From these environmental variables, the trophic index "TRIX" was calculated (Vollenweider et al., 1998; Jorgensen et al., 2005; Melaku et al., 2003).

\section{Seagrass Community Characterization}

The extension of the seagrass meadows in this protected marine area was determined using a Sentinel 2A multispectral image, which has a pixel size of $10 \mathrm{~m}$ and a radiometric resolution of 12 bits. This image corresponds to May 8, 2017 (Path/Row: 21/46) (ESA, 2019), in which the image composition was generated by means of the blue $(490 \mathrm{~nm})$, green $(560 \mathrm{~nm})$, and red (665 $\mathrm{nm}$ ) bands. Once this image composition was obtained, ground masking and radiometric correction (DOS-Dark Object Subtraction) were performed (Chavez, 1988). For the classification of the image, four classes were considered based on an analysis of conglomerates with $80 \%$ similarity. From these classes and field verifications of 117 sites, spectral signatures of four types of seagrass beds were generated (coverage\%, Table 1, Supporting Information): monospecific meadows of Thalassia testudinum (TtMa), mixing seagrass meadows (T. testudinum, S. filiforme, H. wrightii) with macroalgae (MxMa), mixing meadows dominated by Syringodium fliforme (MxSf), and Syringodium filiforme and Thalassia testudinum beds (SfTt). In the latter class, just one sample with $H$. wrigthii was found (Supplementary material, Table 1). The supervised classification was carried out by means of the maximum likelihood estimation. To determine the accuracy of the classification, we determined the Kappa statistic, which measures the level of agreement between the classes (Song et al., 2001). Sampling campaigns were designed to collect data and samples at several stations according to the area of each type of seagrass meadow. The characterization of the seagrass beds consisted of determining coverage (\%) and density, following the Seagrass-Watch percent cover standard (Mckenzie et al. 2001), and they were established at each station using a random scheme. Duplicate samples of seagrass biomass (leaves, rhizomes, and roots) were collected at each station using the standing crop method with a $15 \mathrm{~cm}$ diameter core (CARICOMP, 2001). In the laboratory, biomass samples were cleaned and epiphytes were removed. Once cleaned, samples were subdivided into two components (aboveground and belowground) and dried at $70^{\circ} \mathrm{C}$ until a constant weight was obtained.

Specific morphometric shoot variables evaluated were the maximum length of the leaves of each species, the width of the leaf and number of leaves per shoot (only for T. testudinum), and the leaf area index (LAI), which was calculated for T. testudinum (Bulthuis, 1990). To estimate the average carbon content in the biomass $\left(\mathrm{C}_{\mathrm{bio}}\right)$ of above- and belowground seagrass components, the values of the dry weights $\left(\mathrm{g} \mathrm{Dw} \mathrm{m}^{-2}\right)$ were converted to carbon equivalents using conversion factors for each species: Thallasia testudinum (0.36), Syringodium filiforme (0.32), and Hallodule wrightii (0.34) (Fourqurean \& Zieman 2002; Short et al., 1985, Papiol et al., unpublished data). Afterwards, these values were finally extrapolated to $\mathrm{Mg} \mathrm{C} \mathrm{ha}^{-1}$.

Peerj reviewing PDF | (2020:11:55341:2:0:NEW 15 Jul 2021) 
160

161

162

163

164

165

166

167

168

169

170

171

172

173

174

175

176

177

178

179

180

181

182

183

184

185

186

187

188

189

190

191

192

193

194

195

196

197

198

199

\section{Soil Characteristics}

To determine the carbon storage in the sediments, we used PVC cores $1 \mathrm{~m}$ in length $(\mathrm{n}=62)$. These cores were inserted by manual hammering. Due to the karst characteristics of the continental shelf, core penetration varied from 0.20 to $1 \mathrm{~m}$. All cores were extrapolated to $1 \mathrm{~m}$ long (Howard et al., 2014). Core compaction was less than 5\% in all cases, and compaction was not considered for correction in this study due to the coarse sediment composition. In the lab, the cores revealed high heterogeneity over several layers of sediment and were sliced into $5 \mathrm{~cm}$ sections at different intervals (Supplementary material Data base). Slices were selected for LOI, $\mathrm{OM} \%$ and $\mathrm{C}_{\text {ing } \%}, \mathrm{C}_{\text {org }} \%$, TN\%, and $\mathrm{TP} \%$ determination.

\section{Organic and Carbonate Content}

Each slice $(\mathrm{n}=298)$ was weighed before and after drying at $70^{\circ} \mathrm{C}$ for $48 \mathrm{~h}$ to determine bulk density (BD). Bulk density was calculated as the dry weight of the soil subsamples divided by the volume of the subsample $\left(5 \mathrm{~cm}^{-3}\right)$ and expressed as $\mathrm{g} \mathrm{cm}^{-3}$. All samples were homogenized and combusted at $500^{\circ} \mathrm{C}$ for $4 \mathrm{~h}$ to determine $\mathrm{LOI}(\mathrm{OM} \%)$ and then for $2 \mathrm{~h}$ at $900{ }^{\circ} \mathrm{C}$ to determine the carbonate content $\mathrm{C}_{\text {ing }}(\%)$ (Kendrick and Lavery, 2001; Heiri et al. 2001). $\mathrm{C}_{\text {org }} \%$ (after acidification with $1 \mathrm{~N} \mathrm{HCl}$ to remove carbonates) and nitrogen content (TN\%) were analyzed using a CHN ThermoQuest autoanalyzer (model Flash EA 112, Italy). The $\mathrm{C}_{\text {org }}$ content (Ccorg; $\mathrm{g} \mathrm{C}_{\text {org }} \mathrm{cm}^{3}$ ) of each $5 \mathrm{~cm}$ slice was calculated from the measured $\mathrm{C}_{\text {org }}$ and the $\mathrm{BD}$ of the slice following Eq. (1):

$$
\text { Ccorg }=z \text { slice } * \mathrm{BD}_{\text {slice }} * \operatorname{Corg}_{\text {slice }} / 100
$$

where zslice is the slice thickness $(\mathrm{cm})$, and the $\mathrm{C}_{\text {org }} \%$ content of the slice is divided by 100 to convert $\%$ to grams of $\mathrm{C}_{\text {org }}$ per gram of dry weight. The amount of carbon stored in each core was calculated by summing the $\mathrm{C}_{\text {org }}$ content in each depth increment (slice). $\mathrm{C}_{\text {org }}$ stocks $(\mathrm{Mg} \mathrm{C}$ $\mathrm{ha}^{-1}$ ) were converted to $\mathrm{CO}_{2 \text { equivalents }}$ by multiplying by 3.67 (conversion factor, ratio of molecular weight $\mathrm{CO}_{2}$ to $\mathrm{C}_{\text {org }}$ ). Total phosphorus (TP \%) was determined by the colorimetric method described by Strickland \& Parsons (1972) and Aspila et al., (1976).

\section{Carbon Source}

To determine the organic carbon sources in the sediment, isotopic analysis of $\delta^{13} \mathrm{C}$ and $\delta^{15} \mathrm{~N}$ was performed. Surface layers $(0-5 \mathrm{~cm})$ of sedimentary cores $(\mathrm{n}=24)$ distributed in the north, center, and south of the reserve were selected, considering a water depth gradient of 1 to $5 \mathrm{~m}$ with a maximum distance of $25 \mathrm{~km}$ from the coast. The subsample for organic carbon analysis was dried, weighed, and then dry-sieved through a $1 \mathrm{~mm}$ mesh to remove coarse inorganic particles. 
200 The remaining samples were then acidified with acid $10 \%(\mathrm{HCl})$. The residual samples were

201

202

203

204

205

206

207

208

209

210

211

212

213

214

215

216

217

218

219

220

221

222

223

224

225

226

227

228

229

230

231

232

233

234

235

236

237

238

239

redried and then capsulated for analyses using a mass spectrometer (Delta V Plus) with an instrumental precision of $0.2 \%$. The Standard material for carbon is Pee Dee Belemnite (PDB) limestone, and the nitrogen standard is atmospheric nitrogen. The $\delta^{13} \mathrm{C}$ carbon signal was expressed in parts per thousand (\%), which was obtained by the isotopic ratio of the heavy isotope in relation to the light isotope (Eq. 2):

$$
\delta^{13} C(\% 0)\left[\left(\frac{R_{\text {sample }}}{R_{\text {standar }}}-1\right)\right] \times 1000, R=\frac{\delta^{13} C}{\delta^{12} C}
$$

The relative contribution of different primary producers as potential sources of organic matter in seagrass sediments was estimated using Fits Stable Isotope Mixing Models (SIMMR V. 0. 3) (Parnell et al., 2010, 2013). We ran the mixing models separately for each water depth (1-5 m) sediment, and we only included as potential sources those primary producers for which both $\delta^{13} \mathrm{C}$ and $\delta^{15} \mathrm{~N}$ values were available: macroalgae blades $\left(\delta^{13} \mathrm{C}-13 \pm 0.2 \%\right.$, $\delta^{15} \mathrm{~N} 1.74 \pm 1.59 \%$ ), seagrass leaves $\left(\delta^{13} \mathrm{C}-11 \pm 0.3 \%\right.$, $\delta^{15} \mathrm{~N} 2 \pm 0.2 \%$ ), and mangrove leaves $\left(\delta^{13} \mathrm{C}-29 \pm 2 \%\right.$, $\delta^{15} \mathrm{~N}$ $1.1 \pm 0.09 \%$ ) (Duarte et al., 2018, Campbell \& Fourqurean 2009, Vaslet et al., 2015).

\section{Statistical Analysis}

The frequency distributions of the water quality characteristics, vegetation structures, and sediments (storage and isotopic signatures) of this study generally did not show normality (based on the normality test of Shapiro-Wilk), so differences in the characteristics of these components between depths were evaluated using the nonparametric Kruskal-Wallis test. Variables that showed normality were analyzed using ANDEVA. These analyses were performed using SigmaPlot $12 \AA$ software with a significance level of 0.05 . Tables 1 and 3 in the Results section show the variables with significant differences according to the depth gradient.

\section{Results}

\section{Water Quality}

The trophic state of the water column estimated through the TRIX index showed an average of $3.85 \pm 0.12$, which is in the oligotrophic range. However, this value varied between oligotrophic and mesotrophic. The LPBR coastal water temperature averaged $29 \pm 0.12^{\circ} \mathrm{C}$, while the average water salinity was $35 \pm 2.43$ ups (Table 1 ). DO concentrations averaged $6.92 \pm 0.16 \mathrm{mg} \mathrm{l}^{-1}$, and no hypoxia concentrations were recorded at any depth (Table 1). Light incidence was greatest at $1 \mathrm{~m}$ depth, $(52 \pm 11 \%$ ), and decreased with depth $\mathrm{u}<20 \%$ at $5 \mathrm{~m}$ (Table 1$)$. $\mathrm{NO}_{3_{-}}+\mathrm{NO}_{2_{-}}$in the water column of LPBR averaged 5.26 $\pm 0.79 \mu \mathrm{mol} \mathrm{l}^{-1}$, with the maximum concentration at $3 \mathrm{~m}$ depth (Table 1). SRP averaged $0.35 \pm 0.02 \mu \mathrm{mol} \mathrm{l}^{-1}$, with the highest values at greater depths (Table 1). $\mathrm{NH}_{4}{ }^{+}$averaged $1.20 \pm 0.08 \mu \mathrm{mol} \mathrm{l}^{-1}$, with the highest values at the lowest depths. SRSi

Peerj reviewing PDF | (2020:11:55341:2:0:NEW 15 Jul 2021) 
240 concentrations in the study area averaged 21.6 $\pm 2.7 \mu \mathrm{mol} \mathrm{l}^{-1}$, varying from higher to lower

241 concentrations following the depth gradient or coastal distance (Table 1). Chlorophyll-a (Ch- $a$ )

242 values averaged $2.59 \pm 0.42 \mu \mathrm{g} \mathrm{l}^{-1}$, with the highest concentrations at the lower depths (Table 1).

243

244

245

246

\section{Sediment Characteristics}

247

Sediments in the LPBR had an average bulk density (BD) of $0.31 \pm 0.25 \mathrm{~g} \mathrm{~cm}^{-3}$, and exhibited no

248 significant differences due to the water depth gradient $(\mathrm{gl}=4, \mathrm{H}=5.69, \mathrm{P}=0.223)$. Concentrations of OM\% ranged from 8 to $35 \%$, and these values did show significant differences $(\mathrm{gl}=4$,

249 $\mathrm{H}=126.28, \mathrm{P}<0.001$ ). $\mathrm{C}_{\mathrm{org}} \%$, ranged from 7 to $15 \%$ and decreased with depth (Table 2, gl=4,

250 $\mathrm{H}=29.31, \mathrm{P}<0.001) . \mathrm{C}_{\mathrm{ing}} \%$ increased with water depth and maximun concentration was found at 251 $5 \mathrm{~m}(\mathrm{gl}=4, \mathrm{H}=8.12, \mathrm{P}=0.087) . \mathrm{TN} \%$ and $\mathrm{TP} \%$ did not show significant spatial variation $(\mathrm{gl}=49$, 252 $\mathrm{F}=01.81, \mathrm{P}=0.142$, and $\mathrm{gl}=49, \mathrm{~F}=2.10, \mathrm{P}=0.097$, respectively), while the $\mathrm{TN}: \mathrm{TP}$ ratio varied between 22 and 42 in the depth gradient (Table 2).

254

255

\section{Seagrass Community}

256

257

Seagrass meadows and macroalgae occupied $82 \%(149,613 \mathrm{ha})$ of the LPBR $(181,991 \mathrm{ha})$. The

258 remainder was substrate without vegetation (31,069 ha) (Fig. 2a). Mixing meadows dominated

259 this area with 51,884 ha of MxMa macroalgae (Fig. 2b). The supervised classification allowed

260 for mapping with $73 \%$ accuracy.

261

262

263

Three species, $T$. testudinum, $S$. filiforme, and $H$. wrightii, were recorded in different abundances in both monospecific and mixed meadows. T. testudinum dominated, with an average coverage

264 of $54 \pm 24 \%$ and greater coverage at depths of 1 and $2 \mathrm{~m}$ (Table 3). Syringodium filiforme

265

266 showed an average coverage of $45 \pm 27 \%$, with the greatest abundance at $3 \mathrm{~m}$ depth (50\%). $H$.

267 wrightii, showed an average coverage of $27 \pm 21 \%$, with the highest value at $3 \mathrm{~m}(38 \%)$. Shoot

268

269

270

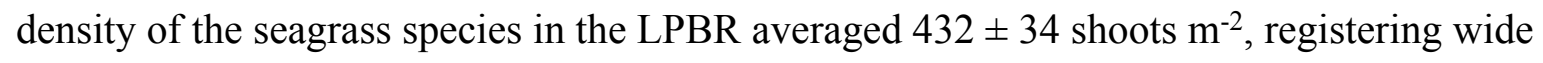
variations between depths.Length of averaged $32 \pm 1.33 \mathrm{~cm}$.T. testudinum leaves averaged was $33 \pm 1.61 \mathrm{~cm}$, with the longest leaves $(\approx 80 \mathrm{~cm})$ at a depth of $2 \mathrm{~m}$. At $5 \mathrm{~m}, T$. testudinum had the widest leaves $(1.2 \pm 0.11 \mathrm{~cm}$ ), and the smallest leaves were found at $1 \mathrm{~m}$ (Table 3$)$. Leaf area

271 index (LAI) averaged $4.06 \pm 0.44$, and the highest average was found at $2 \mathrm{~m}$ depth $(7.75 \pm 1.41)$.

272 Syringodium filiforme showed the longest leaves at $5 \mathrm{~m}(44 \pm 4.67 \mathrm{~cm})$, while $H$. wrightii had the

273 smallest average leaves $(15.6 \pm 2 \mathrm{~cm})$. In relation to biomass, seagrass meadows in the LPBR 274

275 averaged $119 \pm 13$ and $510 \pm 46 \mathrm{~g} \mathrm{Dw} \mathrm{m}^{-2}$ in aboveground and belowground biomass,

276

277 respectively, with the greatest values measured at $2 \mathrm{~m}$ depth (aboveground at $196 \pm 42 \mathrm{~g} \mathrm{Dw} \mathrm{m}^{-2}$, and belowground at $768 \pm 157 \mathrm{~g} \mathrm{Dw} \mathrm{m}^{-2}$ ). Thalassia testudinum had the largest contribution

278 (79\%) to total biomass, which decreased at greater depths when replaced by S. filiforme (Tabla 3). The above/below biomass ratio (AB:BW) averaged 0.32 , which corresponded to $81 \%$ of the 
279

280

281

282

283

284

285

286

287

288

289

290

291

292

293

294

295

296

297

298

299

300

301

302

303

304

305

306

307

308

309

310

311

312

313

314

315

316

317

318

319

320

total biomass (Table 3). Macroalgae coverage decreased with water depth, and there were no significant differences between water depths (Table 4, $\mathrm{gl}=4, \mathrm{H}=10.51, \mathrm{P}=0.033$ ).

\section{Seagrass Carbon Stocks and Sources}

Biomass organic carbon averaged $2.2 \pm 1.7 \mathrm{Mg} \mathrm{C}^{-1}$, with statistically significant differences between water depths $(\mathrm{gl}=4, \mathrm{H}=13.49, \mathrm{P}=0.009$, Table 5). T. testudinum averaged $2 \pm 1.7 \mathrm{Mg} \mathrm{C}$ $\mathrm{ha}^{-1}$ and decreased with water depth (Fig. 3a). S. filiforme and $H$. wrightii averaged $0.88 \pm 0.78$ and $0.89 \pm 1 \mathrm{Mg} \mathrm{C} \mathrm{ha}^{-1}$, respectively, and did not present a trend in the gradient (Fig. 3 b,c). Statistical differences between species were found $(\mathrm{gl}=4, \mathrm{H}=22.44, \mathrm{P}=<0.001)$. In sediment $\left(\mathrm{C}_{\mathrm{sed}}\right)$, Corg storage net averaged $131 \pm 118 \mathrm{Mg} \mathrm{Cha}^{-1}(\mathrm{gl}=4, \mathrm{H}=13.77, \mathrm{P}=0.008)$. In the top $1 \mathrm{~m}$, this stock was $318 \pm 215 \mathrm{Mg} \mathrm{C}^{-1}$, with a maximum of $463 \pm 267 \mathrm{Mg} \mathrm{C} \mathrm{ha}^{-1}$ at $1 \mathrm{~m}$ water $(\mathrm{gl}=$ 4, $\mathrm{H}=6.02, \mathrm{P}=0.197$ ) (Table 5). The $\mathrm{C}_{\text {ing }}$ stock averaged $133 \pm 104 \mathrm{Mg} \mathrm{C}_{\text {ing }}$ ha $^{-1}$, varying with respect to depth $(\mathrm{gl}=4, \mathrm{H}=0.64, \mathrm{P}=0.958$; Table 5$)$. The ecosystem carbon stock $\left(\mathrm{C}_{\text {bio }}+\mathrm{C}_{\text {sed }}\right)$ in Los Petenes Biosphere Reserve was 47Tg C (Table 6). Considering the extension of each type of meadow, those in the MxMa stored the largest $\mathrm{C}_{\text {org }}$ of the study area (34\%). The seagrass meadows dominated by SfTt represented the smallest stock in the area, with $8 \%$ of the total (Fig. 4).

The surface of seagrass sediments averaged $\delta^{13} \mathrm{C}$ of $-17 \pm 3 \%$ and $\delta^{15} \mathrm{~N}$ of $3 \pm 1 \%$. In shallow areas (1-2 m), the $\delta^{13} \mathrm{C}$ varied between -10 and $-24 \%$; in the deeper areas $(4-5 \mathrm{~m}), \delta^{13} \mathrm{C}$ varied between -12 and $-17 \%$, with statistically significant differences between water depths ( $\mathrm{gl}=23$, $\mathrm{F}=3.37, \mathrm{P}=0.030$, Table 7).

$\delta^{15} \mathrm{~N}$ of LPBR sediment ranged from 2 to $3 \%$, and there were no significant differences in the depth gradient ( $\mathrm{gl}=23, \mathrm{~F}=0.64 \mathrm{P}=0.637$; Table 6). Mean $\delta^{13} \mathrm{C}$ and $\delta^{15} \mathrm{~N}$ values of seagrass sediments were within the region defined by $\delta^{13} \mathrm{C}$ and $\delta^{15} \mathrm{~N}$ mean values of primary producers (Fig. 5a). The SMMIR mixing models identified sources of organic matter in seagrass sediments (Fig. 5b and Table 7). Seagrass leaves and macroalgae blades were the major potential contributors in seagrass sediments (mean \pm SD proportion $=0.39 \pm 0.19$ and $0.36 \pm 0.21$, respectively), while mangrove leaves had a minor contribution $(0.24 \pm 0.21)$. The seagrass contribution increased with water depth (Table 7).

\section{Discussion}

\section{Water Quality and Sediment Characteristics}

The marine area Los Petenes Biosphere Reserve showed general oligotrophic conditions. This area, which is on a karstic geomorphological coast, receives groundwater discharge from springs and runoff from channels that connect mangrove areas with the sea (Agraz-Hernandez et al., 2012). Exchange of nutrients at the site reflects high concentrations of $\mathrm{OM} \%, \mathrm{C}_{\mathrm{org}} \%$, and TN\% in the areas near the coastline (1-2 m water depth) (Table 2). The concentration of these nutrients 
321 in the sediment is associated with the type of organic matter that they receive from both

322

323

324

325

326

327

328

329

330

331

332

333

334

335

336

337

338

339

340

341

342

343

344

345

346

347

348

349

350

351

352

353

354

355

356

357

358

359

360

mangroves and submerged aquatic vegetation (SAV), as well as degradation patterns, residence times of the accumulated matter, and the chemical balance of carbonate (Koch et al., 2001). Carbonate concentrations exceeded $20 \%$ in the deep zone (Table 2). N/P ratios show that sediments in the reserve are marine type and are influenced by terrigenous material (Hernández, 2000). Isotopic mangrove signatures in the superficial sediments at $1 \mathrm{~m}$ depth support this finding (Fig. 5; Table 7). In general, concentrations of registered nutrients indicate that there is no limitation of primary production, at least in the first meters of water depth, since the concentrations are in the tolerance range for seagrasses. In karst systems, it is common to observe P limitations (Álvarez-Góngora and Herrera-Silveira, 2006); the connectivity between mangroves and seagrasses in this area, provides favorable conditions for the development of quality SAV. However, this leads to significant vulnerability if groundwater discharges begin to show signs of pollution, as they have in the northern and eastern regions of the Yucatan Peninsula (Herrera-Silveira \& Morales-Ojeda, 2009; Arcega-Cabrera et al., 2014; Kantún et al., 2018). However, due to the connectivity between mangroves and seagrasses, the light and concentration of nutrients in this area favor conditions for the healthy development of SAV.

\section{Seagrass Complexity}

The large area covered by SAV indicates good conditions, as reflected in the spatial continuity of the seagrass meadows, morphometric characteristics, and their biomass (Table 3 ). These characteristics of LPBR seagrasses are useful as baseline data for monitoring the health of the ecosystem. Rapid coastal development experienced by these areas may allow for the identification of responses to different environmental stressors (Tomasko \& Lapointe, 1991; Lirman \& Cropper, 2003; Lee et al., 2007). There was also spatial variability in the specific morphometric and structural characteristics of the seagrass community in the study area with respect to the depth gradient and distance from the coast. This implies changes in variables such as salinity and transparency (Table 1), which control seagrass productivity (Fourqurean et al., 1992).

The structural variability of seagrass beds with respect to depth gradient (Table 3 ) indicates an area where T. testudinum dominates at lower depths, with the presence of patches of $H$. wrightii (coverage of $<5 \%$ ); at greater depths, the dominant species was $S$. filiforme, which is consistent with tropical locations (Tribble, 1981). In the LPBR, T. testudinum and H. wrightii dominated areas with greater salinity variability; $S$. filiforme was common in areas of less salinity variation and lower light requirements, which encouraged its dominance in deeper areas (Zieman et al., 1989; Hall et al., 1999; Lirman \& Cropper, 2003). Biomass, coverage, density, and LAI of T. testudinum was lowest the deepest zone $(5 \mathrm{~m}$ ) (Table 3 ) due to the lowest incidence of light (Olesen et al., 2002; Enríquez \& Pantoja-Reyes, 2005). Additionally, the primary roots of $T$. testudinum were observed to be approximately $30 \mathrm{~cm}$ long. Greater belowground biomass and 
361

362

363

364

365

366

367

368

369

370

371

372

373

374

375

376

377

378

379

380

381

382

383

384

385

386

387

388

389

390

391

392

393

394

395

396

397

398

399

400

rhizomal elongation determine the depth of anchorage of the species and allow it to tolerate erosion processes, therefore contributing to the $\mathrm{C}_{\text {org }}$ stock. In contrast, the dominant seagrass at 5 $\mathrm{m}$ was $S$. filiforme, suggesting that the light requirements vary between species due to the physiological characteristics and morphological adaptations of each (Lee et al., 2007).

Environmental conditions in the LPBR favor the growth of seagrasses (Table 3). Leaf lengths were greater than lengths reported for other regions of the Gulf of Mexico and the Caribbean (Hackney \& Durako, 2004; Arellano-Méndez et al., 2016; Gallegos et al., 1993; van Tussenbroek, 1998). Additionally, the total biomass (above + belowground $=863 \pm 478 \mathrm{~g} \mathrm{Dw} \mathrm{m}^{-}$ ${ }^{2}$ ) was higher than the reported global scale value of $\square 461 \mathrm{~g} \mathrm{Dw} \mathrm{m}^{-2}$ (Duarte \& Chiscano, 1999) and lower than estuarine zone estimates $\left(879 \mathrm{~g} \mathrm{Dw} \mathrm{m}^{-2}\right)$. The structural complexity and favorable environmental conditions in the LPBR reflected in the quantity and quality of the ecosystem services seagrasses provide, such as storing carbon in high concentrations (Fig. 2; Table 6).

\section{Carbon Stocks and Sources Along a Depth Gradient}

In the study area, carbon stored as biomass in seagrasses showed a lower average $(2.2 \pm 1.17 \mathrm{Mg}$ $\left.\mathrm{C} \mathrm{ha}^{-1}\right)$ than those reported on a global scale $\left(3 \pm 0.4 \mathrm{Mg} \mathrm{Cha}^{-1}\right)$, but they were greater than values from the South Atlantic meadows $\left(1 \pm 0.5 \mathrm{Mg} \mathrm{C}^{-1}\right.$; Fourqurean et al., 2012a). Mean sediment stock at the top $1 \mathrm{~m}\left(318 \pm 215 \mathrm{Mg} \mathrm{C}^{-1}\right)$ was in the range reported for seagrasses in the tropical region of Australia (268 $\left.\mathrm{Mg} \mathrm{Cha}^{-1}\right)$ and was greater than the global estimates (194 \pm $20 \mathrm{Mg} \mathrm{C} \mathrm{ha}^{-1}$ ) (Fourqurean et al., 2012a). These results suggest that the study area has a high capacity to capture and store coastal carbon, making it highly relevant for the mitigation of greenhouse gas emissions; it must therefore remain protected.

Both aerial and underground carbon storage showed spatial variability related to depth/distance to the shoreline (Table 5). Some studies for other species have indicated that $\mathrm{C}_{\text {org }}$ storage and sequestration rates in seagrass sediments are higher in shallow meadows and at moderate salinities (Mateo \& Romero, 1997; Serrano et al., 2014). The increase in depth implies a reduction in irradiance and a decrease in salinity, which in part affect the productivity of the seagrasses, their structural complexity, and the species composition, with ultimate consequences on carbon stocks. Hydrodynamics influences the structural complexity of seagrasses and probably influences the storage and carbon fluxes in seagrasses (Mateo \& Romero 1997; Koch et al., 2006; Serrano et al., 2014; Dahl et al., 2016). Although this variable was not evaluated in this study, currents in this area is the lowest $\left(1 \mathrm{~m} \mathrm{sec}^{-1}\right)$ of the three coasts of the Yucatan Peninsula (López and Sierra, 1998), Furthermore, in combination with the low tidal range $(<1 \mathrm{~m})$, hydrodynamic energy must be low, favoring processes such as sedimentation, retention, and decomposition of materials produced both locally and regionally. Such is the case for the area near the coast that receives contributions of organic matter from the adjacent mangrove forest (Fig. 5).

Peer] reviewing PDF | (2020:11:55341:2:0:NEW 15 Jul 2021) 
401

402

403

404

405

406

407

408

409

410

411

412

413

414

415

416

417

418

419

420

421

422

423

424

425

426

427

428

429

430

431

432

433

434

435

436

437

438

439

440

Isotopic values of $\delta^{13} \mathrm{C}$ from surface sediments varied between -10 and $-24 \%$ in relation to distance to the coast. This indicates different sources of organic carbon in the seagrass soils of this area. Near the coast and up to $7 \mathrm{~km}$ from the coast, the isotopic signatures averaged $\delta^{13} \mathrm{C}$ of $21 \pm 4.2 \%$ (Table 7), was is similar to the mangrove sediments enriches with carbonates (Garcias-Bonet et al., 2019). Mangrove contribution to carbon storage decreased with depth, the inverse pattern of the contribution of seagrass is observed (Table 7). Macroalgae blades and seagrass leaves in seagrass sediments were strongly negatively correlated (-0.94) (Fig 5a). This indicates the model could not determine the principal carbon source in sediment, indicating that if macroalgae blades contributed to seagrass sediments at the top of their outcome probability range, seagrass leaves most likely contributed at the bottom of their probability range (Fig. 5a). Stocks of organic carbon in sediments of seagrasses of this protected area were $24 \%$ allochthone sources (mangroves), while 76\% were of autochthon origin (macroalgae and seagrass) (Fig 5b). Therefore, the identification of potential sources and contributions to sediments based on stable isotopes needs to be interpreted with care. These results confirm, first, the connectivity between two coastal ecosystems (mangroves and seagrasses) (de Boer 2000; Serrano et al., 2014) and, simultaneously, the role of seagrasses as sediment traps and sequestrants of allochthonous carbon (Mellors et al., 2002; Hendrix et al., 2008; Samper-Villareal et al., 2016).

\section{Conservation Implications}

Carbon stocks in seagrass meadows of this protected natural area vary according to the extent of each type of seagrass meadow, with a total of $47 \mathrm{Tg} \mathrm{C}_{\text {org }}$ (Table 6). This value contrasts with the estimate of Thorhaug et al., (2017) of 37-38 $\mathrm{Tg} \mathrm{C}_{\text {org }}$ for the entire Gulf of Mexico estimates for Mexico (48 $\mathrm{Tg} \mathrm{C}_{\text {org }}$ ), where the higher stock is located in the Yucatan Peninsula (HerreraSilveira et al., 2020). Seagrasses, mangroves, and salt marshes, are collectively called blue carbon ecosystems (Howard et al., 2014; Howard et al., 2017). Disturbance of these system can increase $\mathrm{CO}_{2}$ emissions as the carbon in the necromass and surface sediment oxidizes.

Mineralization of the carbon stored in LPBR could relase $173 \mathrm{Tg}$ of $\mathrm{CO}_{2 \mathrm{eq}}$. This corresponds to emissions generated by $27 \%$ of the current Mexican population, based on per capita emissions from fossil fuel consumption estimated for 2009 (3.72 $\left.\mathrm{t} \mathrm{CO}_{2}\right)($ Cavazos et al., 2013). The loss of vegetation cover in the Gulf of Mexico has been progressively decreasing, with an estimated $50 \%$ decrease from 1,927,500 ha in 1992 to 947,327 ha in 2017 (Duke et al., 1992; Thorhaug et al., 2017); this loss is equivalent to an estimated annual loss rate of vegetation in the region of approximately $3 \%$ over a span of 25 years. The seagrass meadows in the LPBR have the largest extension of seagrasses in Mexico, with 149,613 ha currently reported. Therefore, if the coastal vegetation in this reserve disappeared at the same estimated annual rate, in 25 years, only $30 \%$ of the current extension would remain. This would likely significantly reduce the ability of the LPBR to offer its current environmental benefits.

Peer] reviewing PDF | (2020:11:55341:2:0:NEW 15 Jul 2021) 
441 The coastal platform of the Yucatan Peninsula is shallow with a steep slope of $\square 1: 1000$ (Zavala442 Hidalgo et al., 2003); the bottom in areas near the coast, therefore, are covered with submerged 443 aquatic vegetation, mainly seagrasses dominated by T. testudinum (Espinoza-Avalos, 1996; van 444 Tussenbroek et al., 2014). Hydrodynamic conditions, such as the speed of the currents and their 445 exposure to hydrometeorological events, such as hurricanes, storms, and cold fronts, could 446 explain the differences in the seagrass cover of the three coasts of the Yucatan Peninsula (Day et 447 al., 2019). On the coast of Quintana Roo, currents average $25 \mathrm{~cm} \mathrm{sec}^{-1}$, and patches of scattered 448 seagrasses covering between 10 and 50\% of the available area (Badan et al., 2005; Arellano449 Méndez et al., 2005). On the northern Yucatan coast, currents range between 10 and $20 \mathrm{~cm} \mathrm{sec}^{-1}$, 450 with seagrass patches covering between 40 and $80 \%$ of the available area (Appendini et al., 451 2012; Kantun -Manzano et al., 2018). Finally, on the coast of Campeche, where the Los Petenes 452 protected area is located, currents are very low at $\square 10 \mathrm{~cm} \mathrm{sec}^{-1}$ (López and Sierra, 1998), 453 favoring the extension and coverage of seagrasses.

454

455

456

457 The LPBR has the largest extension of the seagrass community in the Gulf of Mexico. Carbon 458 stored (76\%) is from seagrass and macroalgae sources. Allochthon contribution decreased and 459 seagrass contribution increased with depth. The results of this study improve estimations of 460 organic carbon storage ( $47 \mathrm{Tg}$ ) in a marine protected area and demonstrate the importance of 461 blue carbon stocks in the subtropics.

462

463

464

\section{Acknowledgements}

This research was partially financially supported by the Mexican Ministry of Energy through the Hydrocarbon Found, project 201441. This is a contribution of the Gulf of Mexico Research Consortium (CIGoM). We acknowledge PEMEX'S specific request to the Hydrocarbon Found to address the environmental effects of oil spills in the Gulf of Mexico. We thanks to Primary Production Lab group from the Centro de Investigación y de Estudios Avanzados del Instituto Politécnico-Unidad Mérida (CINVESTAV-IPN, Unidad Mérida). Special thanks to the Consejo

472 Cecilia Cota Lucero. Thanks to M. Sc. Juan Enrique Mendoza Martínez for his technical support 473 and the editors of this article. Thanks to National Commission of Natural Protected Areas 474 (CONANP) especially to the Yucatan Peninsula and Mexican Caribbean Regional Direction, as 475 well to Direction of the natural protected area of the Biosfera Reserve Los Petenes for the 476 support and facilities to seagrasses sampling field trips.

477

\section{References}

479 
480 Agraz-Hernández, CM, Osti-Sáenz J, Chan-Keb G, Expósito-Díaz E, Márquez-García J, Acosta 481 S, Reyes-Castellanos JE, Conde-Medina KP, Cach-Ruiz MY. 2012.Los ecosistemas de manglar 482 en el estado de Campeche: Diagnóstico de la conservación e identificación de áreas potenciales 483 para la restauración. Informe final. Fondos Mixtos del Gobierno del estado de Campeche y 484 Ciencia y Tecnología (CONACyT-Fomix). Universidad Autónoma de Campeche. Clave $4851264430,179$.

486

487

Álvarez-Góngora, C, Herrera-Silveira JA. 2006. Variations Of Phytoplankton Community

489 Structure Related To Water Quality Trends In A Tropical Karstic Coastal Zone. Marine

490 Pollution Bulletin 52:48-60 DOI: 10.1016/j.marpolbul.2005.08.006.

492

Arcega-Cabrera F, Noreña Barroso E, Oceguera-Vargas I. 2014. Lead from hunting activities and its potential environmental threat to wildlife in a protected wetland in Yucatan, Mexico. Ecotoxicology and Environmental Safety 100:251-257 DOI: 10.1016/j.ecoenv.2013.11.002.

494

Arellano-Méndez L, Morales-Ojeda SM, Herrera-Silveira JA. 2015. Carbono orgánico de las praderas de Thalassia testudinum en Bahía de la Ascensión (Quintana Roo, México). Una primera estimación del contenido de carbono azul en una laguna costera del Caribe Mexicano. In: Estado Actual del Conocimiento del Ciclo del Carbono y sus Interacciones en México: Síntesis, eds. Paz F, Wong J. Texcoco, Estado de México, México. 421-427.

500

501

Arellano-Méndez LU, Bello-Pineda J, Aké-Castillo JA, Pérez-España H, Martínez-Cárdenas L.

502 2016. Distribución espacial y estructura morfométrica de las praderas de Thalassia testudinum

503

504 (Hydrocharitaceae) en dos arrecifes del Parque Nacional Sistema Arrecifal Veracruzano,

505

506

507

508

509

510 México. Revista de Biología Tropical. 64: 427-448.

Aspila KI, Agemian H, Chau SY. 1976. A Semi-automated method for determination of inorganic, organic and total phosphate in sediments. Analyst 101:187-197. DOI:10.1039/AN9760100187.

Appendini CM, Salles P, Mendoza ET, López J, Torres-Freyermuth A. 2012. Longshore sediment transport on the northern coast of the Yucatan Peninsula. Journal of Coastal Research. 28:1404-1417 DOI: 10.2112/JCOASTRES-D-11-00162.1.

512

513 Badan Jr A, Candela J, Sheinbaum J, Ochoa J. 2005. Upper-layer circulation in the approaches to 514 Yucatan Channel. Washington DC American Geophysical Union Geophysical Monograph 515 Series 161:57-69.

516

517 Bouillon S, Borges AV, Castaneda-Moya E, Diele K, Dittmar T, Duke NC, Kristensen E, Lee

518 SY, Marchand C, Middelburg JJ, Rivera-Monroy VH, Smith III TJ, Twilley RR. 2008.

519 Mangrove production and carbon sinks: A revision of global Budget estimates. Global

520 Biogeochemical Cycles 22 DOI:10.1029/2007GB003052. 
522

523 Carmen B, Krause-Jensen D, Alcoverro T, Marbà N, Duarte CM, Van Katwijk MM, Pérez M, 524 Romero J, Sanchez-Lizaso JL, Roca G, Jankowska E. 2019. Recent trend reversal for declining 525 European seagrass meadows. Nature communications 10:1-8 DOI: 10.1038/s41467-019-113405264.

527

528 CARICOMP. 2001. CARICOMP Methods Manual - Level I: Manual of methods for mapping 529 and monitoring of physical and biological parameters in the coastal zone of the Caribbean Mona, 530 Kingston, Jamaica. U.S.A.

531

532

533

Campbell JE, Fourqurean JW. 2009. Interspecific variation in the elemental and stable isotope content of seagrasses in South Florida. Marine Ecology Progress Series 387:109-123

534 DOI:10.3354/meps08093

535

536 Cavazos T, Salinas JA, Martínez B, Colorado G, de Grau P, Prieto-González R, Bravo ME. 537 2013. Actualización de escenarios de cambio climático para México como parte de los productos

538 de la Quinta Comunicación Nacional. informe, México, Instituto Nacional de Ecología y Cambio 539 Climático.

540

541 Charpy-Roubaud C, Sournia A. 1990. The comparative estimation of phytoplanktonic,

542 Microphytobenthic and macrophytobenthic primary production in the oceans. Marine Microbial

543 Food Webs 4:31-57.

544

545 Chavez Jr PS. 1988. An improved dark-object subtraction technique for atmospheric scattering 546 correction of multispectral data. Remote Sensing of Environment 24:459-479.

547

548 CONAGUA. 2006. Programa Hidráulico Regional 2002-2006, Península de Yucatán, Región 549 XII. SEMARNAT.

550

551 Corbalá JA, Del Río J, García MJ. 2007. Diversidad, distribución y abundancia de moluscos en 552 la región de Los Petenes. Escuela Superior de Ciencias Agropecuarias. Universidad Autónoma 553 de Campeche. Bol. Inf. JAINA 17: 1-15.

554

555 Costanza R, de Groot R, Sutton P, Van der Ploeg S, Anderson SJ, Kubiszewski I, Farber S, 556 Turner K. 2014. Changes in the global value of ecosystem services. Global Environmental 557 Change 26:152-158 DOI:10.1016/j.gloenvcha.2014.04.002. 
559 Dahl M, Deyanova D, Lyimo LD, Näslund J, Samuelsson GS, Mtolera MS, Bjork M, Gullstrom 560 M. 2016. Effects of shading and simulated grazing on carbon sequestration in a tropical seagrass 561 meadow. Journal of Ecology 104:654-664 DOI: 10.1111/1365-2745.12564.

562

563 Day JW, Domínguez ALL, Herrera-Silveira JA, Kemp GP. 2019. Climate change in areas of the 564 Gulf of Mexico with high freshwater input a review of impacts and potential mitigation. JAINA.

565 Costas y Mares ante el Cambio Climático 1: 87-108.

566

567 de Boer WF. 2000. Biomass dynamics of seagrasses and the role of mangrove and seagrass

568 vegetation as different nutrient sources for an intertidal ecosystem. Aquatic Botany 66:225-239

569 DOI:10.1016/S0304-3770(99)00072-8.

570

571 Duarte CM, Cebrián J. 1996. The fate of marine autotrophic production. Limnology and

572 Oceanography 41:1758-766 DOI: 10.4319/lo.1996.41.8.1758.

573

574 Duarte CM, Chiscano CL. 1999. Seagrass biomass and production: a reassessment. Aquatic

575 Botany 65:159-174 DOI: 10.1016/S0304-3770(99)00038-8.

576

577

Duarte CM, Sintes T, Marbà N. 2013. Assessing the $\mathrm{CO}_{2}$ capture potential of seagrass restoration

578

579

580 projects. Journal of Applied Ecology 50: 1341-1349 DOI: 10.1111/1365-2664.12155.

581

Duarte CM, Krause-Jensen D. 2017. Export from seagrass meadows contributes to marine

582

583 Duarte CM, Delgado-Huertas A, Anton Gamazo A, Carrillo-de-Albornoz P, López-Sandoval D. carbon sequestration. Frontiers in Marine Science 4-13:1-7 DOI:10.3389/fmars.2017.00013.

584 C, Duarte A, Manuel C, Delgado-Huertas, Antonio; Anton, Andrea; Carrillo-de-Albornoz,

585 Paloma; López-Sandoval, Daffne C, Agusti S, Hanan A, Marbà N, Hendriks I, Krause-Jensen D, 586 Garcias-Bonet N.2018. Stable isotope $\left(\delta^{13} \mathrm{C}, \delta^{15} \mathrm{~N}, \delta^{18} \mathrm{O}, \delta \mathrm{D}\right)$ composition and nutrient

587 concentration of Red Sea primary producers. Frontiers in Marine Science 5:298

588 DOI:10.3389/fmars.2018.00298.

589

590 Duke T, Kruczynski W. 1992. A summary of the report: Status and trends of emergent and 591 submerged vegetated habitats of the Gulf of Mexico, USA. The Environmental and Economic

592 Status of the Gulf of Mexico Gulf of Mexico Program, Stennis, Mississippi. 11-28.

593

594 Enríquez S, Pantoja-Reyes NI. 2005. Form-function analysis of the effect of canopy morphology 595 on leaf self-shading in the seagrass Thalassia testudinum. Oecologia 145: 234-242.

596 DOI:10.1007/s00442-005-0111-7.

597 
598 Espinoza-Avalos J. 1996. Distribution of seagrasses in the Yucatan Peninsula, Mexico. Bulletin 599 of Marine Science 59: 449-454.

600

601 European Space Agency. 2018. Copernicus

602 Sentinel.https://sentinel.esa.int/web/sentinel/missions/sentinel-2. [Accessed 29 april 2018].

603

604 Fourqurean JW, Zieman, JC, Powell GV. 1992. Relationships between pore water nutrients and 605 seagrasses in a subtropical carbonate environment. Marine Biology. 114:57-65 DOI:

606 10.1007/BF00350856.

607

608

609

Fourqurean JW, Zieman, JC. 2002. Nutrient content of the seagrass Thalassia testudinum reveals

610 regional patterns of relative availability of nitrogen and phosphorus in the Florida Keys USA.

611

612 Fourqurean JW, Duarte CM, Kennedy H, Marbà N, Holmer M, Mateo MA, Apostolaki ET, 613 Kendrick GA, Krause-Jensen D, McGlathery KJ, Serrano O. 2012a. Seagrass ecosystems as a 614 globally significant carbon stock. Nature Geoscience 5: 505-509 DOI: 10.1038/ngeo1477.

615

616 Gacia E, Duarte CM, Middelburg JJ. 2002. Carbon and nutrient deposition in a Mediterranean 617 seagrass (Posidonia oceanica) meadow. Limnology and Oceanography. 23-32

618 DOI:10.4319/lo.2002.47.1.0023.

619

620

Gallegos-Martínez E, Merino M, Marbá N, Duarte CM. 1993. Biomass and dynamics of

621 Thalassia testudinum in the Mexican Caribbean: elucidating rhizome growth. Marine Ecology

622

623

624 Progress Series 185-192 DOI:10.3354/meps095185.

625 Garcias-Bonet N, Delgado-Huertas A, Carrillo-de-Albornoz P, Anton A, Almahasheer H, Marbà

626 N, Hendriks IE, Krause-Jensen D, Duarte CM. 2019. Carbon and nitrogen concentrations, stocks,

627 and isotopic compositions in Red Sea seagrass and mangrove sediments. Frontiers in Marine

628

629 Science 6:267 DOI: 10.3389/fmars.2019.00267.

630 Caribe. Datos Geofísicos Serie A. Oceanografía. Instituto de Geofisica Universidad Nacional 631 Autónoma de México.

632

633

Hackney JW, Durako MJ. 2004. Size frequency patterns in morphometric characteristics of the 634 seagrass Thalassia testudinum reflect environmental variability. Ecological Indicators 4:55-71

635 DOI:10.1016/j.ecolind.2003.12.001.

636 
637 Hall MO, Durako MJ, Fourqurean JW, Zieman, JC. 1999. Decadal changes in seagrass

638 distribution and abundance in Florida Bay. Estuaries 22: 445-459 DOI:10.2307/1353210.

639

640 Hemminga MA, Nieuwenhuize J. 1990. Seagrass wrack-induced dune formation on a tropical

641 coast (Banc d'Arguin, Mauritania). Estuarine, Coastal and Shelf Science 31: 499-502 DOI:

642 10.1016/0272-7714(90)90040-X.

643

644 Hendriks IE, Sintes T, Bouma TJ, Duarte CM. 2008. Experimental assessment and modeling 645 evaluation of the effects of the seagrass Posidonia oceanica on flow and particle trapping,

646 Marine Ecology Progress Series 356:163-173 DOI:10.3354/meps07316.

647

648 Herrera-Silveira JA, Comín FA. 2000. An introductory account of the types of aquatic

649 ecosystems of Yucatan Peninsula (SE Mexico). In: EcoVision World Monographs Series.

650 Aquatic Ecosystems of Mexico: Status and Scope, eds. Munawar, M, Lawrence SG, Munawar IF, 651 Malley DF. Backhuys Pub., Leiden 213-227.

652

653

Herrera-Silveira JA, Morales-Ojeda SM. 2009. Evaluation of the health status of a coastal

654 ecosystem in southeast Mexico: Assessment of water quality, phytoplankton and submerged

655 aquatic vegetation. Marine Pollution Bulletin 59:72-86 DOI: 10.1016/j.marpolbul.2008.11.017.

656

657

Herrera-Silveira JA, Pech-Cardenas MA, Morales-Ojeda SM, Cinco-Castro S, Camacho-Rico A, 658 Sosa JP, Teutli-Hernandez C. 2020. Blue carbon of Mexico, carbon stocks and fluxes: a

659 systematic review. PeerJ 8:e8790. DOI:10.7717/peerj.8790.

660

661

Hernández MVF. 2000. Nitrógeno, fósforo y cociente C/N en los sedimentos superficiales de la

662

663

664 laguna de Chacopata, Sucre, Venezuela. Revista de Biología Tropical 261-268.

665

Howard J, Hoyt S, Isensee K, Pidgeon E, Telszewski M. 2014. Coastal Blue Carbon: Methods

666 for assessing carbon stocks and emissions factors in mangroves, tidal salt marshes, and seagrass

667 meadows. Conservation International, Intergovernmental Oceanographic Commission of

668

669 UNESCO, International Union for Conservation of Nature. Arlington, Virginia, USA.

670

Howard J, Sutton-Grier A, Herr D, Kleypas J, Landi E, Mcleod E, Pidgeon E, Simpson S. 2017.

671 Clarifying the role of coastal and marine systems in climate mitigation. Frontiers in Ecology and the Environment 5: 42-50 DOI:10.1002/fee.1451.

672

673

Jorgensen SE, Xu FL, Salas F, Marques JC. 2005. Application of indicators for the assessment of 674 ecosystem health. Eds. Jurgensen SE, Constanza R. Handbook of Ecological Indicators for 675 Assessment of Ecosystem Health, USA: Taylor \& Francis.6. 676 
677 Kantun-Manzano CA, Arcega-Cabrera F, Derrien M, Noreña-Barroso E, Herrera-Silveira JA.

678 2018. Submerged groundwater discharges as source of fecal material in protected karstic coastal 679 areas. In protected karstic coastal areas. Geofluids 11 DOI:10.1155/2018/9736260.

680

681 Koch EW. 2001. Beyond light: Physical, geological and geochemical parameters as possible 682 submersed aquatic vegetation habitat requirements. Estuaries 24: 1-17 DOI:10.2307/1352808.

683

684 Koch EW, Ackerman JD, Verduin J, van Keulen M. 2006. Fluid dynamics in seagrass ecology 685 from molecules to ecosystems. In Seagrasses: biology, ecology and conservation. Springer, 686 Dordrecht 193-225.

687

688

689

Laffoley D, Grimsditch G. 2009. The Management of Natural Coastal Carbon Sinks. IUCN. Gland, Switzerland.

690

691 Lee KS, Park SR, Kim YK. 2007. Effects of irradiance, temperature, and nutrients on growth

692

693 dynamics of seagrasses: a review. Journal of Experimental Marine Biology and Ecology

694

695 350:144-175 DOI:10.1016/j.jembe.2007.06.016.

696

697

Lirman D, Cropper WP. 2003. The influence of salinity on seagrass growth, survivorship, and distribution within Biscayne Bay, Florida: field, experimental, and modeling studies. Estuaries 26: 131-141 DOI:10.1007/BF02691700.

698

699

López BM, Sierra AP. 1998. Circulación del Golfo de México inducida por mareas, viento y la 700 corriente de Yucatán. Ciencias Marinas 24:65-93.

701

702

703

704

Mateo MA, Romero J. 1997. Detritus dynamics in the seagrass Posidonia oceanica: elements for an ecosystem carbon and nutrient budget. Marine Ecology Progress Series 151:43-53.

DOI:10.3354/meps 151043.

705

706

707

708

709

710

McKenzie LJ. 2003. Guidelines for the rapid assessment and mapping of tropical seagrass habitats. Department of Primary Industries. The State of Queensland 17-18.

711

712

713 Mateo-Cid LE, Mendoza-González AC, Ávila-Ortiz AG, Díaz-Martínez S. 2013. Algas marinas 714 bentónicas del litoral de Campeche, México. Acta Botánica Mexicana 104:3-92.

715 
716 McLeod E, Chmura GL, Bouillon S, Salm R, Björk M, Duarte CM, Lovelock CE, Schlesinger 717 WH, Silliman BR. 2011. A blueprint for blue carbon: toward an improved understanding of the 718 role of vegetated coastal habitats in sequestering $\mathrm{CO}_{2}$. Frontiers in Ecology and the Environment 719 9: 552-560 DOI: 10.1890/110004.

720

721 Melaku D, Solidoro C, Umgiesser G. 2003. Modelling the responses of the lagoon of Venice 722 ecosystem to variations in physical forcing. Ecological Modeling 170:265-289.

723 Mellors J, Marsh H, Carruthers TJ, Waycott M. 2002. Testing the sediment-trapping paradigm of 724 seagrass: Do seagrasses influence nutrient status and sediment structure in tropical intertidal 725 environments? Bulletin of Marine Science 71: 1215-1226.

726

727

Nellemann C, Corcoran E, Duarte CM, Valdés L, De Young C, Fonseca L, Grimsditch G. 2009.

728

729 Blue carbon. A Rapid Response Assessment. United Nations Environment Programme, GRIDArendal.

730

731

732

Olesen B, Enríquez S, Duarte CM, Sand-Jensen K. 2002. Depth acclimation of photosynthesis, morphology and demography of Posidonia oceanica and Cymodocea nodosa in the Spanish

733 Mediterranean Sea. Marine Ecology Progress Series 236:89-97 DOI: 10.3354/meps236089.

734

735

Orth RJ, Carruthers TJB, Dennison WC, Duarte CM, Fourqurean JW, Heck KL, Hughes, Gary

736 AR, Kendrick A, Kenworthy WJ, Olyarnik S, Short FT, Waycott M, Williams SL.2006. A

737 Global Crisis for Seagrass Ecosystems, BioScience 56: 987-96 DOI:10.1641/0006-

738 3568(2006)56[987: AGCFSE]2.0.CO;2.

739

740

Parnell AC, Inger R, Bearhop S, Jackson AL. 2010. Source partitioning using stable isotopes:

741 coping with too much variation. PLOS ONE 5: e9672.

742

743 Parnell AC, Phillips DL, Bearhop S, Semmens BX, Ward EJ, Moore JW, Jackson AL, Grey J, 744 Kelly DJ, Inger R. 2013. Bayesian stable isotope mixing models. Environmetrics 24:387-399 745 DOI:10.1002/env.2221.

746

747 Pérez-Espinosa I, Gallegos-Martínez ME, Ress1 RA, Valderrama-Landeros LH, Hernández748 Cárdenas G. 2019. Spatial distribution of seagrasses and submerged aquatic vegetation of los 749 Petenes, Campeche. Terra Digitalis 3:1-37 DOI: 10.22201/igg.25940694.2019.2.56.

750

Peterson BJ, Howarth RW. 1987. Sulfur, carbon, and nitrogen isotopes used to trace organic 752 753 matter flow in the salt-marsh estuaries of Sapelo Island. Georgia Limnology Oceanography 32:1195-1213 DOI:10.4319/lo.1987.32.6.1195.

754 
755 Samper-Villarreal J, Lovelock CE, Saunders MI, Roelfsema C, Mumby PJ. 2016. Organic 756 carbon in seagrass sediments is influenced by seagrass canopy complexity, turbidity, wave 757 height, and water depth. Limnology and Oceanography 61: 938-952 DOI: 10.1002/lno.10262.

758

759

760

761

762

763

764

765

766

767

768

769

770

771

772

773

774

775

776

777

778

779

780

781

782

783

784

785

786

787

788

789

790

791

792

793

794

Serrano O, Lavery PS, Rozaimi M, Mateo MÁ. 2014. Influence of water depth on the carbon sequestration capacity of seagrasses. Global Biogeochemical Cycles 28: 950-961.

DOI:0.1002/2014GB004872.

Short FT, Davis MW, Gibson RA, Zimmermann CF. 1985. Evidence for phosphorus limitation in carbonate sediments of the seagrass Syringodium filiforme. Estuarine, Coastal and Shelf Science 20:419-430 DOI: 10.1016/0272-7714(85)90086-1.

Short F, Carruthers T, Dennison W, Waycott M. 2007. Global seagrass distribution and diversity: a bioregional model. Journal of Experimental Marine Biology and Ecology 350: 3-20 DOI: 10.1016/j.jembe.2007.06.012.

Signa G, Mazzola A, Kairo J, Vizzini S. 2017. Small-scale variability in geomorphological settings influences mangrove-derived organic matter export in a tropical bay. Biogeosciences 14: 617-629 DOI: 10.5194/bg-14-617-2017.

Song C, Woodcock CE, Seto KC, Lenney MP, Macomber SA. 2001. Classification and change detection using Landsat TM data: when and how to correct atmospheric effects? Remote Sensing of Environment 75:230-244 DOI: 10.1016/S0034-4257(00)00169-3.

Strickland JD, Parsons TR. 1972. A practical handbook of seawater analysis. Fisheries Research Board of Canada. Ottawa.

Tanaya T, Watanabe K, Yamamoto S, Hongo C, Kayanne H, Kuwae T. 2018. Contributions of the direct supply of belowground seagrass detritus and trapping of suspended organic matter to the sedimentary organic carbon stock in seagrass meadows. Biogeosciences 15: 4033-4045. DOI: 10.5194/bg-15-4033-2018.

Thorhaug A, Poulos HM, López-Portillo J, Ku TC, Berlyn GP. 2017. Seagrass blue carbon dynamics in the Gulf of Mexico: Stocks, losses from anthropogenic disturbance, and gains through seagrass restoration. Science of the Total Environment 605:626-636. DOI: 10.1016/j.scitotenv.2017.06.189.

Tribble GW. 1981. Reef-basel herbivores and the distribution of two seagrasses (Syringodium filiforme and Thalassia testudinum) in the San Blas Islands (Western Caribbean). Marine Biology 65: 277-281 DOI:10.1007/BF00397122.

Peer] reviewing PDF | (2020:11:55341:2:0:NEW 15 Jul 2021) 
795

796 Tomasko, D. A., \& Lapointe, B. E. 1991. Productivity and biomass of Thalassia testudinum as

797 related to water column nutrient availability and epiphyte levels: field observations and

798 experimental studies. Marine ecology Progress Series.

799

800 Vaslet A, Bouchon-Navarro Y, Harmelin-Vivien M, Lepoint G, Louis M, Bouchon C. 2015.

801 Foraging habits of reef fishes associated with mangroves and seagrass beds in a Caribbean

802 lagoon: A stable isotope approach. Ciencias marinas 41: 217-232. DOI:10.7773/cm.v41i3.2494.

803

804 van Tussenbroek BI. 1998. Above-and below-ground biomass and production by Thalassia

805 testudinum in a tropical reef lagoon. Aquatic Botany 61: 69-82 DOI: 10.1016/S0304-

806 3770(98)00058-8.

807

808 van Tussenbroek BI, Cortés J, Collin R, Fonseca AC, Gayle PM, Guzman HM, Rodríguez-

809 Ramírez, A. 2014. Caribbean-wide, long-term study of seagrass beds reveals local variations,

810 shifts in community structure and occasional collapse. PloS ONE 9:3 DOI:

811 10.1371/journal.pone.0090600.

812

813 Vollenweider RA, Giovanardi F, Montanari G, Rinaldi A. 1998. Characterization of the trophic

814 conditions of marine coastal waters with special reference to the NW Adriatic Sea: proposal for a

815 trophic scale, turbidity and generalized water quality index. Environmetrics: The Official Journal

816 of the International Environmetrics Society 9:329-357.

817

818 Waycott M, Duarte CM, Carruthers TJ, Orth RJ, Dennison WC, Olyarnik, S. 2009. Accelerating

819 loss of seagrasses across the globe threatens coastal ecosystems. Proceedings of the National

820 Academy of Sciences 106:12377-12381 DOI: 10.1073/pnas.0905620106.

821

822 Zieman J, Fourqurean JW, Iverson RL. 1989. Distribution, abundance and productivity of

823 seagrasses and macroalgae in Florida Bay. Bulletin of Marine Science 44:292-311. 
Figure 1

Study area

a) Study area, imagen showing the location of seagrass (black circles), preprosed sentinel $2 \mathrm{~A}$ image. Image was acquired on May 8, 2017 (Path/Row: 21/46) pixel size 10 m.Black line (LPBR limits). b) Los Petenes Biosphere Reserve (LPBR), in the Gulf of Mexico in Campeche, México.

$\mathbf{a}$

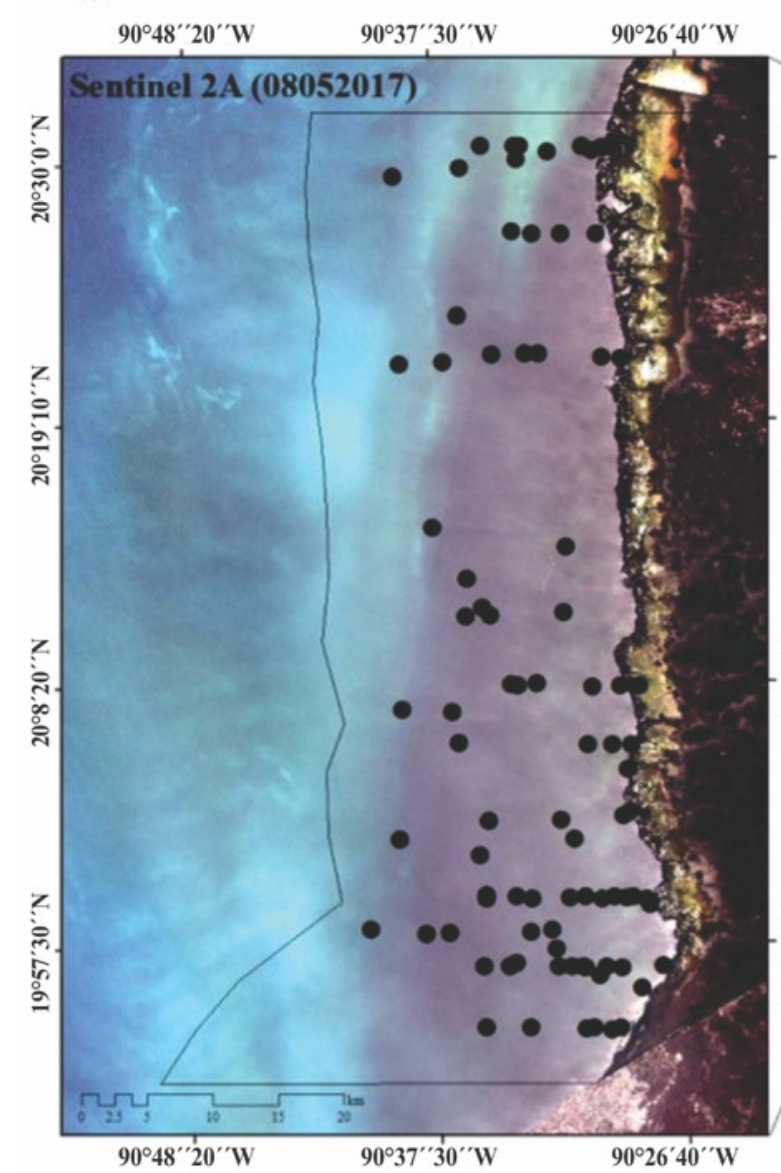

b

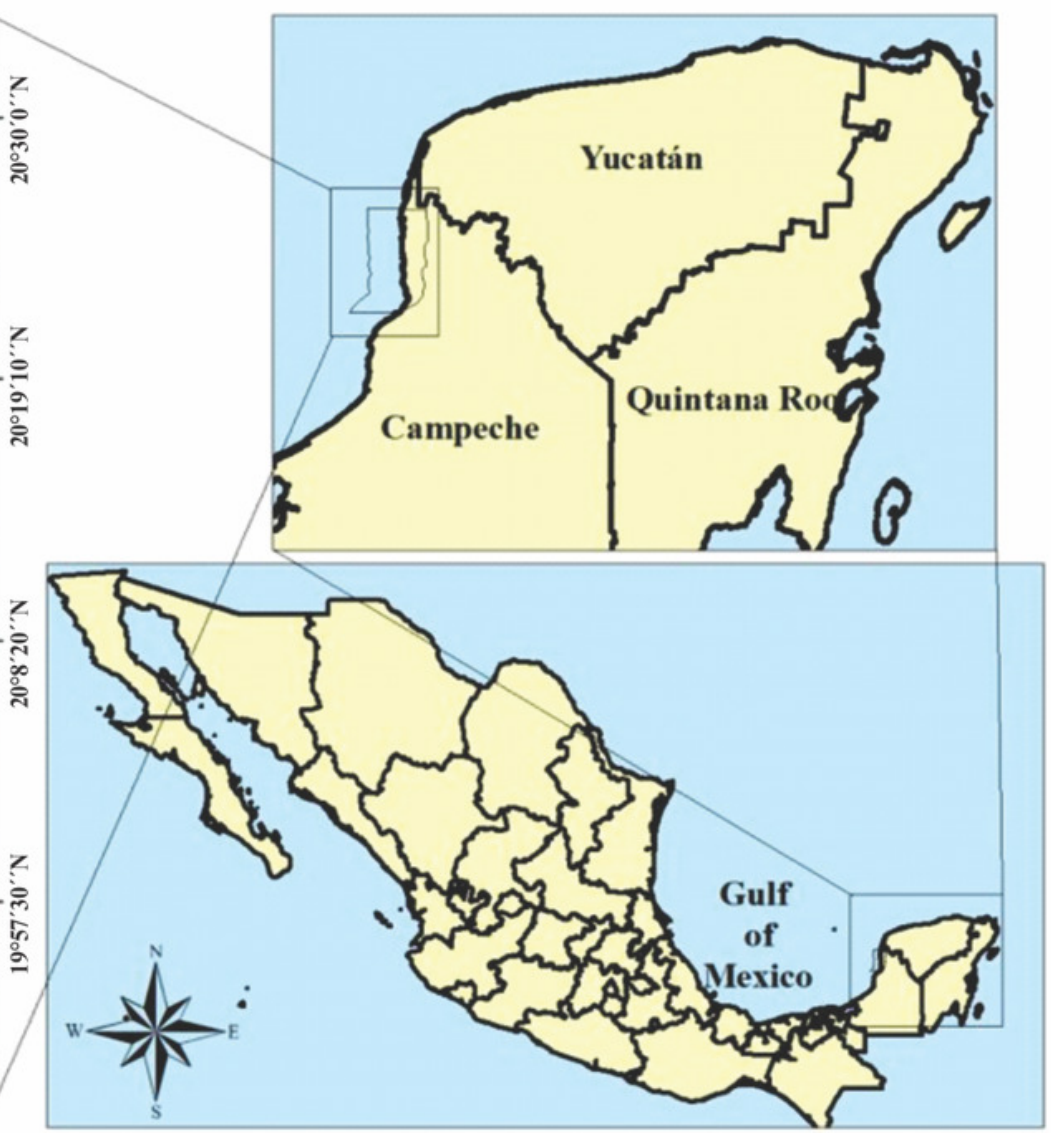


Figure 2

Seagrass meadows

Seagrass distribution.a) seagrass classes based on species coverage. b) supervised classification sentinel 2A, extension of seagrass in LPBR (ha).
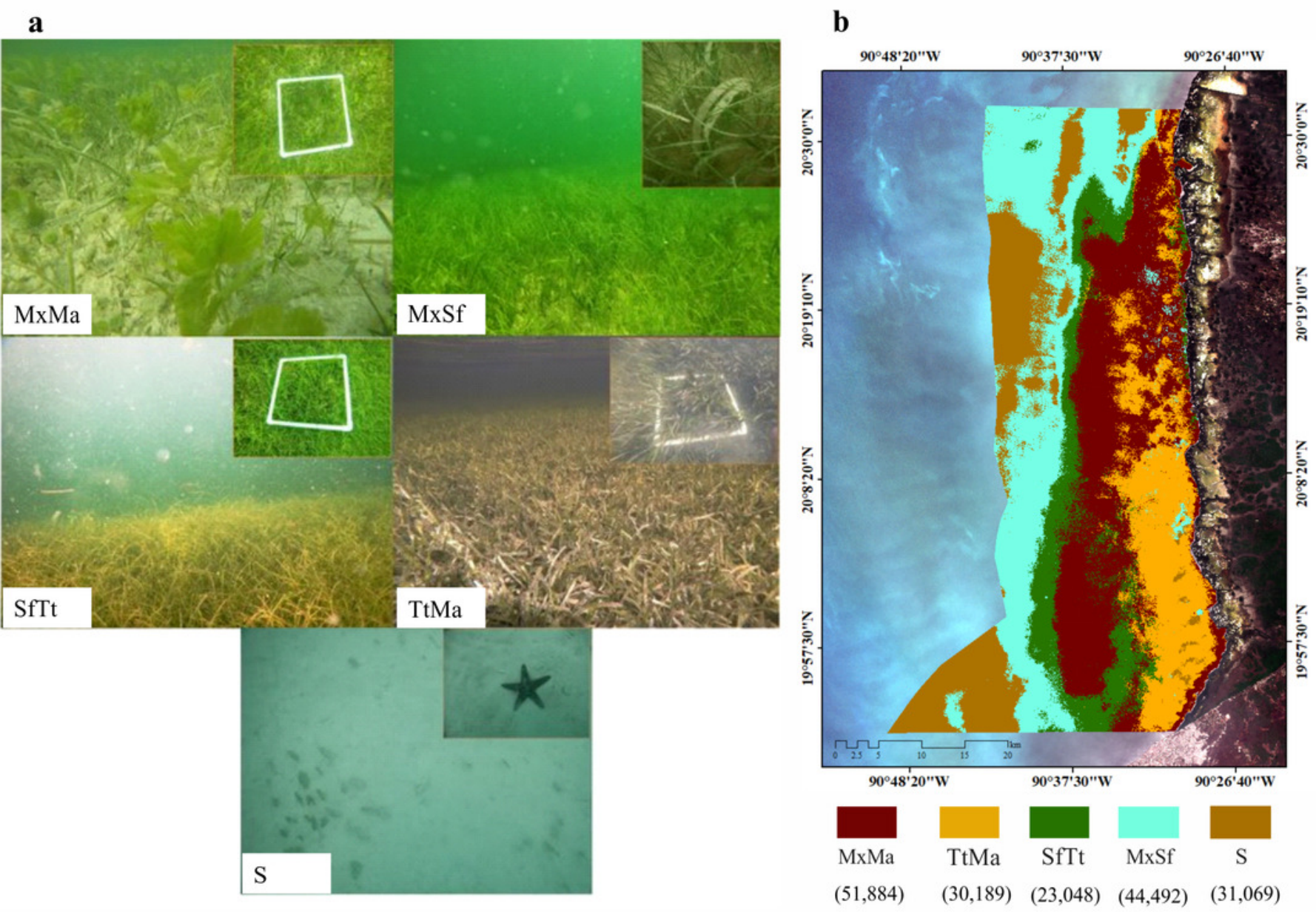
Figure 3

Carbon stocks of seagrass species

Carbon stocks of seagrass species at different water depths(1-5 m depth): a) comparison of thalassia testudinum. b) comparison of Syringodium filiforme. c) comparison of Halodule wrightii 
a

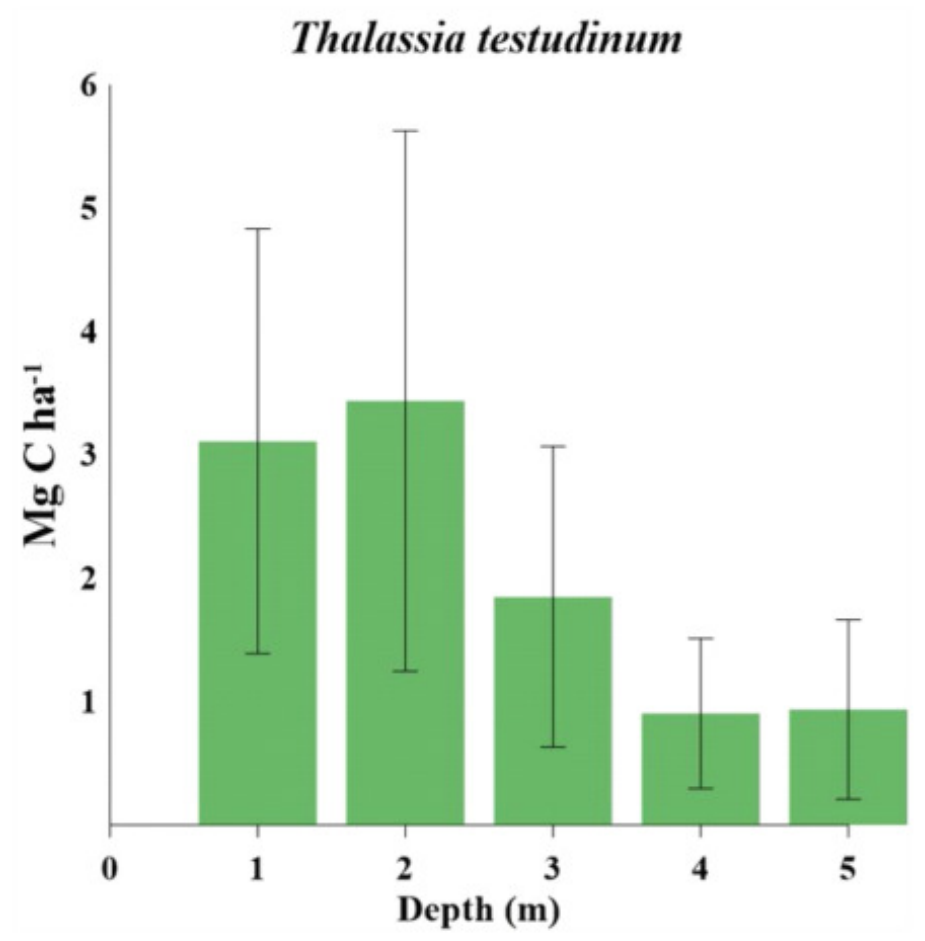

c

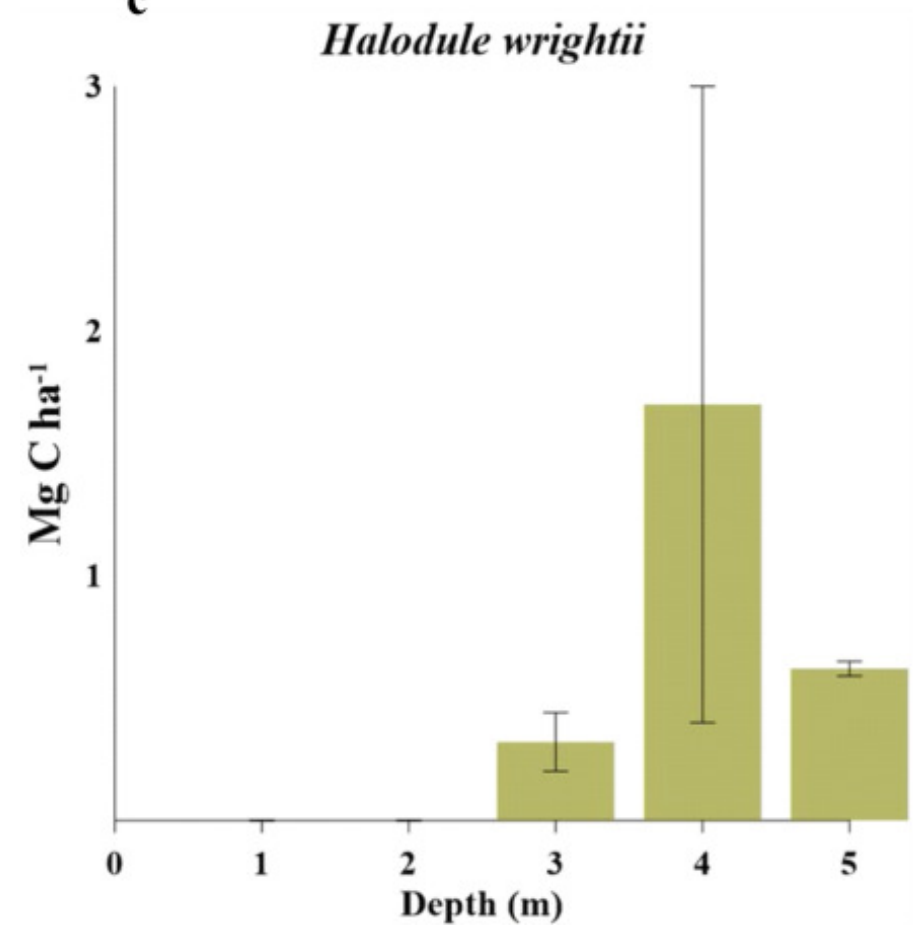

b

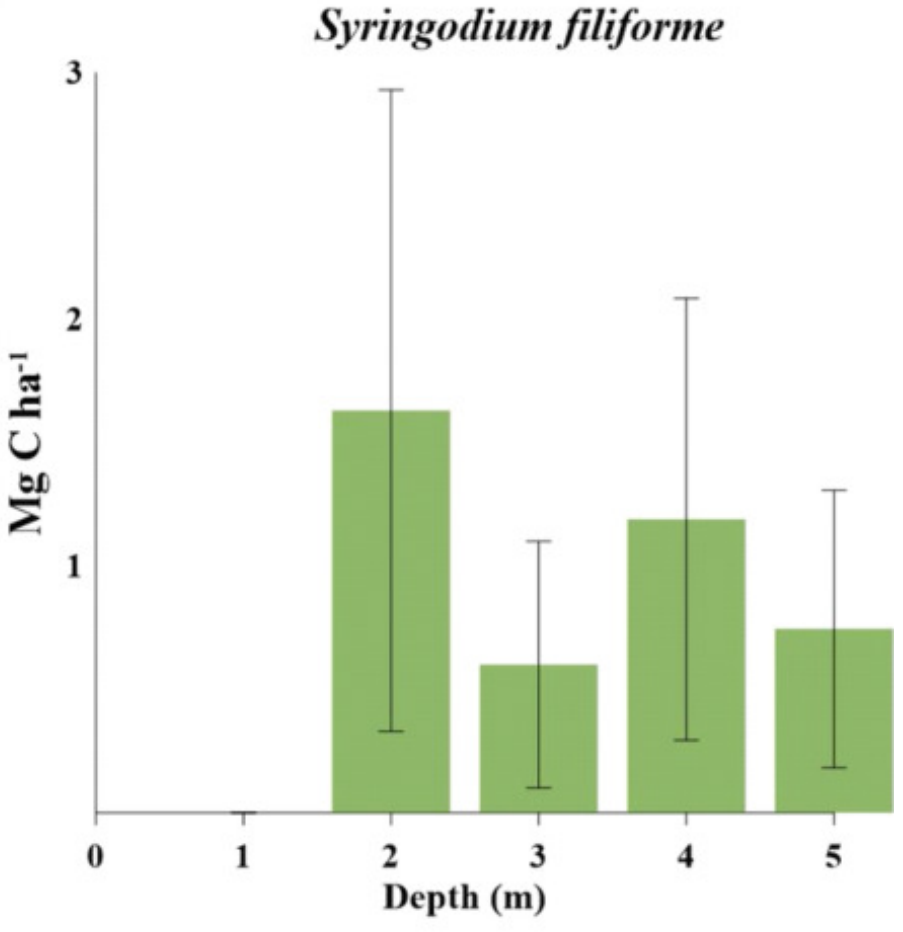


Figure 4

\section{Carbon stocks}

Carbon stocks (biomass + sediments (top $1 \mathrm{~m}$ )) of seagrass classes in LPBR. 


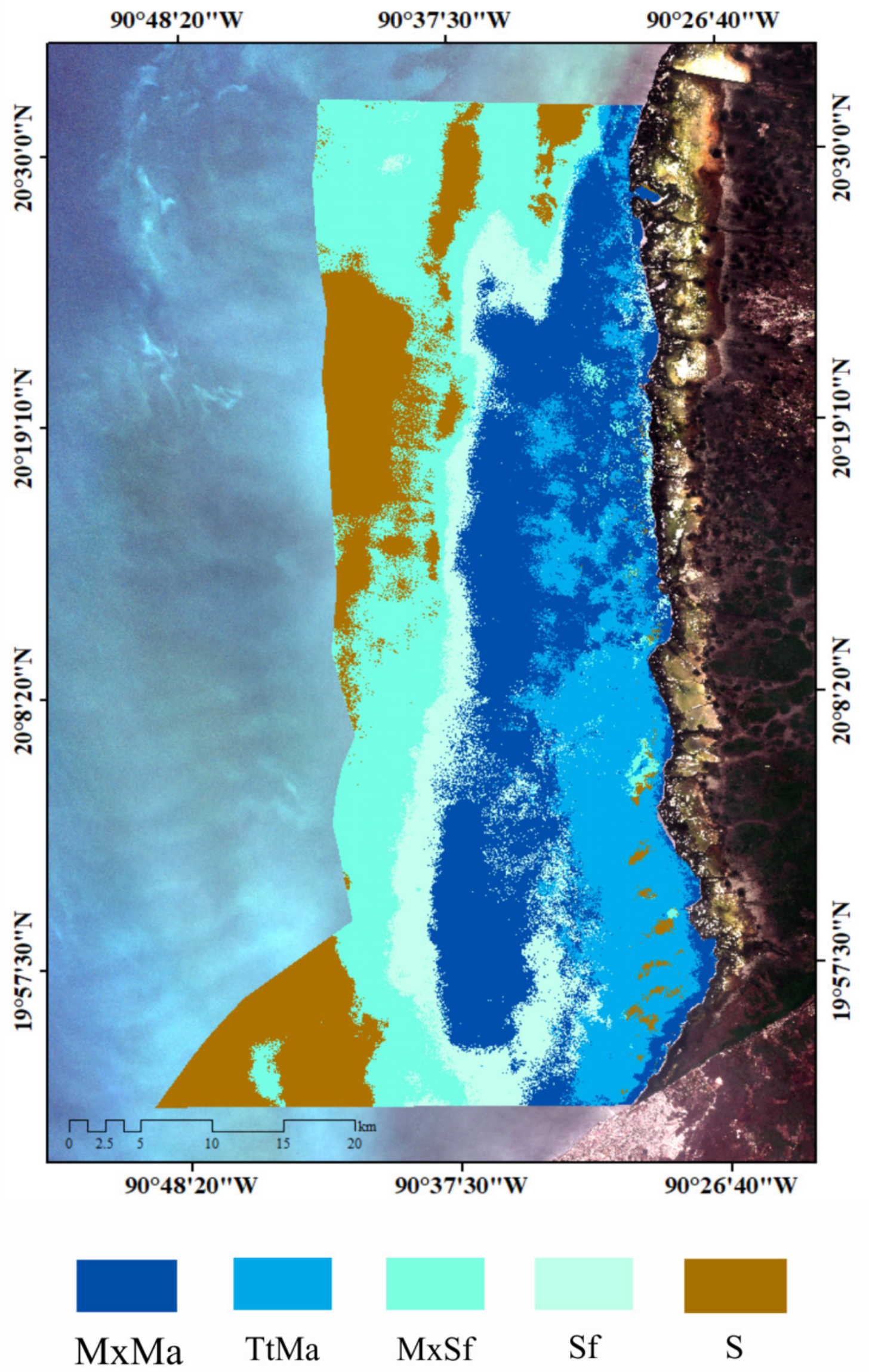




\section{Figure 5}

Contribution of seagrass

Contribution of seagrass, macroalgae and mangrove to the accumulated carbon organic in seagrass $(a, b)$ sediments in the LPBR calculated using Bayesian mixing models. Matrix plots for seagrass (a) sediments, showing probability distributions of each source (in diagonal panels), the joint probability between pairs of sources (in top panels), and the correlations between pairs of sources (in bottom panels). b) Box plots of the proportional contribution by each source to seagrass sediments. Boxes extend from the 25th to 75th percentiles and lines inside boxes represent mean values.

\section{Contribution of sources to sediment}

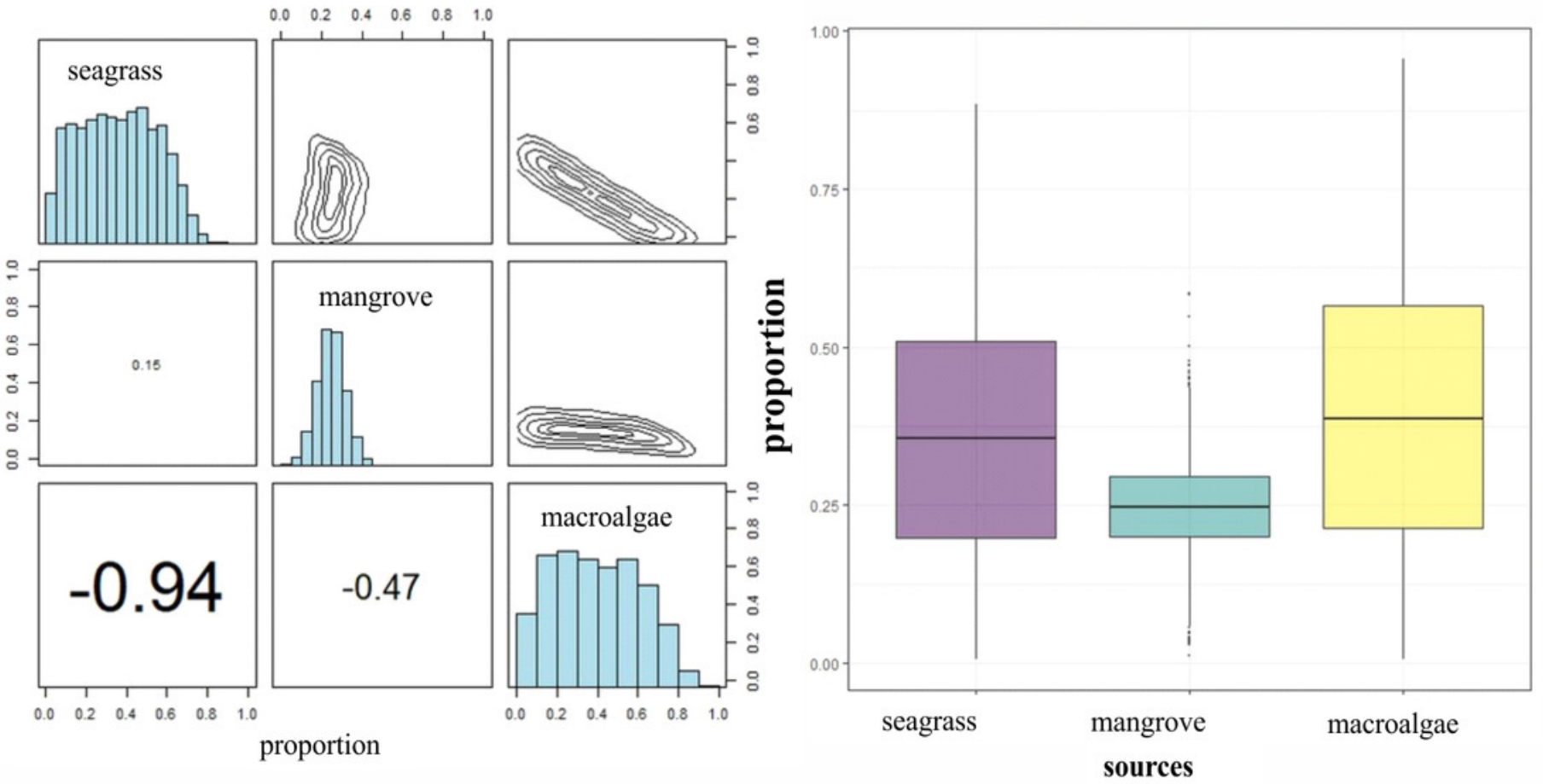




\section{Table $\mathbf{1}$ (on next page)}

Summary of the distribution of the water quality variables

Summary of water quality parameter measured in LPBR at different water depths(1-5 m depth), showing mean $\pm S D$, median, minimum and maximum values.Statistical data test (ANDEVA and Kruskall-wallis test). black letters represent statistical differences. 


\begin{tabular}{|c|c|c|c|c|c|c|c|c|}
\hline Depth & $1 \mathrm{~m}$ & $2 \mathrm{~m}$ & $3 \mathrm{~m}$ & $4 \mathrm{~m}$ & $5 \mathrm{~m}$ & $\mathrm{gl}$ & $\begin{array}{c}\text { Critical } \\
\text { value }\end{array}$ & $P$ \\
\hline Temperature $\left({ }^{\circ} \mathrm{C}\right)$ & & & & & & 84 & $\mathrm{~F}=0.85$ & 0.497 \\
\hline Mean \pm SD & $29.11 \pm 0.51$ & $28.60 \pm 0.31$ & $29.23 \pm 0.24$ & $28.44 \pm 0.20$ & $29.06 \pm 0.68$ & & & \\
\hline Median & 28 & 28 & 29 & 28 & 28 & & & \\
\hline Min-Max & $28-32$ & $27-31$ & $27-34$ & $27-30$ & $27-39$ & & & \\
\hline \multicolumn{9}{|l|}{ Sal (ups) } \\
\hline Mean \pm SD & $36 \pm 4.1$ & $37 \pm 2$ & $36 \pm 2.4$ & $35 \pm 1.7$ & $34 \pm 1.3$ & 4 & $H=16.19$ & 0.003 \\
\hline Median & 37 & 38 & 36 & 35 & 35 & & & \\
\hline Min-Max & $28-41$ & $34-40$ & $31-41$ & $31-37$ & $31-35$ & & & \\
\hline$O D\left(\mathrm{mg} \mathrm{l}^{-1}\right)$ & & & & & & 4 & $\mathbf{H}=\mathbf{1 7}$ & 0.002 \\
\hline Mean \pm SD & $8.67 \pm 0.73$ & $6.73 \pm 0.47$ & $7.03 \pm 0.15$ & $6.31 \pm 0.30$ & $6.31 \pm 0.18$ & & & \\
\hline Median & 9 & 7 & 7 & 6 & 6 & & & \\
\hline Min-Max & $5-12$ & $3-9$ & $5-9$ & $3-8$ & $5-8$ & & & \\
\hline \multicolumn{6}{|c|}{$\mathrm{NO}_{2-}+\mathrm{NO}_{3-}\left(\mu \mathrm{mol} \mathrm{l} \mathrm{l}^{-1}\right)$} & 76 & $\mathrm{~F}=2.04$ & 0.098 \\
\hline Mean \pm SD & $2.37 \pm 0.73$ & $6.13 \pm 2.03$ & $7.53 \pm 1.56$ & $4.53 \pm 1.79$ & $1.73 \pm 0.20$ & & & \\
\hline Median & 2.19 & 2.08 & 2.91 & 1.77 & 1.67 & & & \\
\hline Min-Max & $0.66-7.23$ & $0.37-19.23$ & $0.05-26.14$ & $0.75-25.74$ & $0.76-3.30$ & & & \\
\hline $\operatorname{SRP}\left(\mu \mathrm{mol} \mathrm{l} \mathbf{l}^{-1}\right)$ & & & & & & 78 & $\mathrm{~F}=0.19$ & 0.943 \\
\hline Mean \pm SD & $0.35 \pm 0.08$ & $0.32 \pm 0.04$ & $0.36 \pm 0.04$ & $0.38 \pm 0.08$ & $0.38 \pm 0.08$ & & & \\
\hline Median & 0.28 & 0.3 & 0.3 & 0.3 & 0.22 & & & \\
\hline Min-Max & 0.150 .70 & $0.10-0.60$ & $0.11-0.80$ & $0.11-1.16$ & $0.10-0.81$ & & & \\
\hline $\mathrm{NH}_{4+}\left(\mu \mathrm{mol} \mathrm{l^{-1 }}\right)$ & & & & & & 78 & $F=3.7$ & 0.008 \\
\hline Mean \pm SD & $1.38 \pm 0.27$ & $1.24 \pm 0.23$ & $1.51 \pm 0.13$ & $1 \pm 0.20$ & $0.64 \pm 0.09$ & & & \\
\hline Median & 1.47 & 1.14 & 1.44 & 0.71 & 0.58 & & & \\
\hline Min-Max & $0.24-2.66$ & $0.18-3.48$ & $0.27-3.14$ & $0.28-3.38$ & $0.14-1.21$ & & & \\
\hline SRSi $\left(\mu \mathrm{mol} \mathrm{l} \mathbf{l}^{-1}\right)$ & & & & & & 80 & $\mathrm{~F}=1.75$ & 0.146 \\
\hline Mean \pm SD & $38.94 \pm 8.58$ & $15.95 \pm 3.18$ & $25.19 \pm 4.31$ & $17.94 \pm 6.85$ & $14.09 \pm 9.07$ & & & \\
\hline Median & 31.69 & 12.54 & 19.73 & 7.97 & 4.16 & & & \\
\hline Min-Max & $8.10-75.13$ & $3.88-48.22$ & $2.90-82.94$ & $0.42-112$ & $0.33-121.7$ & & & \\
\hline $\mathrm{Cl} a\left(\mu \mathrm{g} \mathrm{l}^{-1}\right)$ & & & & & & 33 & $\mathrm{~F}=0.59$ & 0.667 \\
\hline Mean \pm SD & $3.41 \pm 0.59$ & $2.85 \pm 1.47$ & $2.88 \pm 1.19$ & $3 \pm 1.12$ & $1.59 \pm 0.32$ & & & \\
\hline Median & 3.22 & 1.36 & 1.82 & 1.33 & 1.49 & & & \\
\hline Min-Max & $1.91-5.15$ & $1-11.65$ & $0.5-8.23$ & $0.96-6.77$ & $0.29-3.70$ & & & \\
\hline TRIX & & & & & & 30 & $\mathrm{~F}=1.35$ & 0.277 \\
\hline Mean \pm SD & $4.53 \pm 0.16$ & $3.45 \pm 0.69$ & $4.17 \pm 0.35$ & $3.63 \pm 0.60$ & $3.38 \pm 0.16$ & & & \\
\hline Median & 4.57 & 4 & 3.74 & 3.67 & 3.32 & & & \\
\hline Min-Max & $3.97-4.97$ & $0.14-4.83$ & $3.50-5.07$ & $2.96-4.51$ & $2.77-4.34$ & & & \\
\hline
\end{tabular}




\section{Table 2 (on next page)}

Summary of sediment quality parameter

Summary of sediment quality parameter, organic matter (OM \%), organic carbon (Corg \%), inorganic carbon (Cing \%), total nitrogen (TN \%), total phosphorus TP (\%), ratio nitrogenphosphorus (N/P) measured in LPBR at different water depths(1-5 $\mathrm{m}$ depth), showing mean \pm SD. 
1

\begin{tabular}{clcccccc}
\hline Depth $(\mathrm{m})$ & $\begin{array}{l}\text { Bulk } \\
\text { density } \\
\left(\mathrm{g} \mathrm{cm}^{-3}\right)\end{array}$ & $\mathrm{OM}(\%)$ & $\mathrm{C}_{\text {org }}(\%)$ & $\mathrm{C}_{\text {ing }}(\%)$ & $\mathrm{TN}(\%)$ & $\mathrm{TP}(\%)$ & $\mathrm{N} / \mathrm{P}$ \\
\hline 1 & $0.28 \pm 0.22$ & $35.66 \pm 20.62$ & $17.28 \pm 6.70$ & $3.79 \pm 3.32$ & $2.72 \pm 1.58$ & $0.18 \pm 0.07$ & $41.60 \pm 34.45$ \\
2 & $0.29 \pm 0.20$ & $22.38 \pm 13.88$ & $11.10 \pm 3.79$ & $3.67 \pm 1.07$ & $2.41 \pm 0.79$ & $0.25 \pm 0.08$ & $22.06 \pm 5.70$ \\
3 & $0.40 \pm 0.29$ & $11.06 \pm 5.29$ & $8.64 \pm 0.88$ & $3.82 \pm 0.79$ & $2.10 \pm 1.18$ & $0.20 \pm 0.06$ & $27.17 \pm 17.36$ \\
4 & $0.30 \pm 0.24$ & $12.27 \pm 7.51$ & $8.33 \pm 1.19$ & $3.33 \pm 0.53$ & $3.17 \pm 0.97$ & $0.22 \pm 0.04$ & $32.07 \pm 11.95$ \\
5 & $0.30 \pm 0.2$ & $8.48 \pm 5.48$ & $7.38 \pm 1.53$ & $3.82 \pm 0.74$ & $3.78 \pm 2.17$ & $0.20 \pm 0.01$ & $42.07 \pm 26.26$ \\
\hline
\end{tabular}

2 


\section{Table 3(on next page)}

Summary of seagrass community

Summary of seagrass community and structure measured in LPBR at different water depths(1-5 m depth), showing mean \pm SD, median, minimum and maximum values.Statistical data test (ANDEVA and Kruskall-wallis test). black letters represent statistical differences. 


\begin{tabular}{|c|c|c|c|c|c|c|c|c|c|c|c|}
\hline Species & Depth & km & $\begin{array}{l}\text { AB } \\
\text { gDW m-2 }\end{array}$ & $\begin{array}{l}\text { BW } \\
\text { gDWm }^{-2}\end{array}$ & $\begin{array}{l}\text { Ratio } \\
\text { AB:BW }\end{array}$ & $\begin{array}{l}\text { Leaf } \\
\text { Length } \\
\text { (cm) }\end{array}$ & $\begin{array}{l}\text { Leaf } \\
\text { Width } \\
\text { (cm) }\end{array}$ & $\begin{array}{l}\text { \#Leaf/ } \\
\text { shoot }\end{array}$ & $\begin{array}{l}\text { \#shoots } \\
\mathbf{m}^{-2}\end{array}$ & $\begin{array}{c}\text { Coverage } \\
(\%)\end{array}$ & LAI \\
\hline T. testudinum & 1 & $0.01-8$ & & & & & & & & & \\
\hline $\operatorname{Mean} \pm \mathrm{SD}$ & & & $95 \pm 49$ & $768.35 \pm 443$ & 0.12 & $23 \pm 9$ & $0.8 \pm 0.16$ & $4 \pm 1$ & $460 \pm 400$ & $75 \pm 25$ & $3.14 \pm 2.2$ \\
\hline Median & & & 103.23 & 871.32 & & 20.75 & 0.82 & 4 & 270 & 80 & 2.27 \\
\hline Min-Max & & & $17.64-158.62$ & $29.41-1392$ & & $15-44$ & $0.50-1$ & $3-6$ & $168-1235$ & $40-100$ & $0.67-6$ \\
\hline T. testudinum & 2 & $2-10$ & & & & & & & & & \\
\hline Mean \pm SD & & & $196 \pm 163$ & $758.22 \pm 493$ & 0.25 & $42 \pm 20$ & $0.9 \pm 0.20$ & $4 \pm 0.7$ & $434 \pm 230$ & $74 \pm 31$ & $7.75 \pm 5.45$ \\
\hline Median & & & 169.7 & 598.23 & & 35.62 & 0.8 & 4 & 416 & 90 & 7.9 \\
\hline Min-Max & & & $9.4-560$ & $70.29-1647.05$ & & $15.25-80.2$ & $0.6-1.35$ & $3-6$ & $112-840$ & $20-100$ & $0.5-15$ \\
\hline \multicolumn{12}{|l|}{ S. filiforme } \\
\hline Mean \pm SD & & & $45 \pm 10$ & $466 \pm 432$ & 0.09 & $19 \pm 16$ & & & $794 \pm 331$ & $45 \pm 45$ & \\
\hline Median & & & 46 & 250 & & 18 & & & 794 & 30 & \\
\hline Min-Max & & & $35-45$ & $185-964$ & & $13-26.5$ & & & 560-1029 & $30-75$ & \\
\hline T. testudinum & 3 & $3-14$ & & & & & & & & & \\
\hline Mean \pm SD & & & $77 \pm 68$ & $438.52 \pm 302$ & 0.17 & $29 \pm 8$ & $0.9 \pm 0.23$ & $4 \pm 1$ & $334 \pm 169$ & $46 \pm 28$ & $3.44 \pm 2.43$ \\
\hline Median & & & 48.97 & 447.05 & & 27 & 0.8 & 4 & 294 & 40 & 2.45 \\
\hline Min-Max & & & $10-279.41$ & $21-1050$ & & $15.77-49.67$ & $0.3-1.5$ & $2-6$ & $58-794$ & $10-100$ & $0.23-8.76$ \\
\hline \multicolumn{12}{|l|}{ S. filiforme } \\
\hline Mean \pm SD & & & $40 \pm 38$ & $125 \pm 137$ & 0.32 & $30 \pm 11$ & & & $364 \pm 294$ & $50 \pm 33$ & \\
\hline Median & & & 25.98 & 89.4 & & 29 & & & 121.5 & 30 & \\
\hline Min-Max & & & $3.52-129.41$ & $7.05-435.29$ & & $11.5-53$ & & & $117-1058$ & $15-100$ & \\
\hline \multicolumn{12}{|l|}{ H.wrightii } \\
\hline Mean \pm SD & & & $13 \pm 7$ & $79 \pm 35$ & 0.17 & $20 \pm 7$ & & & $574 \pm 234$ & $38 \pm 33$ & \\
\hline Median & & & 13.13 & 94.11 & & 21 & & & 587 & 30 & \\
\hline Min-Max & & & $5.88-23.52$ & $17.64-102.94$ & & $10-28$ & & & $300-823$ & $10-75$ & \\
\hline T. testudinum & 4 & $10-17$ & & & & & & & & & \\
\hline Mean \pm SD & & & $53 \pm 46$ & $201 \pm 167$ & 0.26 & $34 \pm 12$ & $1 \pm 0.19$ & $4 \pm 0.8$ & $345 \pm 282$ & $53 \pm 27$ & $3.84 \pm 4.12$ \\
\hline Median & & & 35.88 & 182.35 & & 27 & 0.9 & 3.5 & 264 & 50 & 2.66 \\
\hline Min-Max & & & $13.52-153.52$ & $14.11-568.82$ & & $21.65-56.50$ & $0.8-1.52$ & $2-5$ & $25-882$ & $15-100$ & $0.20-12.37$ \\
\hline \multicolumn{12}{|l|}{ S. filiforme } \\
\hline Mean \pm SD & & & $121 \pm 132$ & $250 \pm 166$ & 0.48 & $29 \pm 12$ & & & $772 \pm 646$ & $41 \pm 28$ & \\
\hline Median & & & 52.94 & 238.52 & & 24 & & & 735 & 37.5 & \\
\hline Min-Max & & & $5.88-411.76$ & $29.41-517.64$ & & $12-14$ & & & $64-2000$ & $10-90$ & \\
\hline \multicolumn{12}{|l|}{ H.wrightii } \\
\hline $\operatorname{Mean} \pm \mathrm{SE}$ & & & $171 \pm 138$ & $346 \pm 266$ & 0.49 & $13 \pm 1$ & & & $1418 \pm 252$ & $25 \pm 14$ & \\
\hline Median & & & 175 & 344 & & 13 & & & 1239 & 25 & \\
\hline Min-Max & & & $5.88-329$ & $37-658$ & & $12-14$ & & & $1239-1596$ & $15-35$ & \\
\hline T. testudinum & 5 & $11-25$ & & & & & & & & & \\
\hline Mean \pm SD & & & $64 \pm 60$ & $113 \pm 51$ & 0.56 & $35 \pm 15$ & $1.2 \pm 0.3$ & $4 \pm 1$ & $128 \pm 80$ & $38 \pm 11$ & $1.3 \pm 0.8$ \\
\hline Median & & & 48.52 & 126.47 & & 38.77 & 1 & 3 & 128 & 40 & 1.73 \\
\hline Min-Max & & & $11.76-147.35$ & $41.17-161.76$ & & $16.45-60$ & $0.6-1.8$ & $2-5$ & $10-252$ & $15-50$ & $0.1-2.17$ \\
\hline \multicolumn{12}{|l|}{ S. filiforme } \\
\hline Mean \pm SD & & & $78 \pm 60$ & $154 \pm 141$ & 0.50 & $44 \pm 18$ & & & $573 \pm 329$ & $48 \pm 20$ & \\
\hline Median & & & 64.7 & 100.88 & & 44.5 & & & 646 & 50 & \\
\hline Min-Max & & & $11.47-191.17$ & $52.94-511.76$ & & $14-64$ & & & $144-1000$ & $10-80$ & \\
\hline \multicolumn{12}{|c|}{ H.wrightii $(n=1)$} \\
\hline Mean \pm SD & & & 5.8 & 170.58 & 0.03 & $14 \pm 1.5$ & & & $466 \pm 274$ & $27 \pm 20$ & \\
\hline Median & & & & & & 14 & & & 411 & 20 & \\
\hline Min-Max & & & & & & $13-16$ & & & $224-764$ & $10-80$ & \\
\hline \multirow[t]{3}{*}{ T. testudinum } & $\mathbf{P}$ & & & & & 0.011 & 0.003 & 0.066 & 0.007 & $<0.001$ & 0.003 \\
\hline & Critical value & & & & & $H=13$ & $H=16$ & $\mathrm{~F}=2.31$ & $F=3.84$ & $F=5.46$ & $H=16.39$ \\
\hline & gl & & & & & 4 & 4 & 74 & 74 & 79 & 4 \\
\hline \multirow[t]{3}{*}{ S. filiforme } & $\mathbf{P}$ & & & & - & 0.013 & & & 0.326 & 0.811 & \\
\hline & Critical value & & & & & $F=4.07$ & & & $\mathrm{H}=3$ & $\mathrm{H}=0.96$ & \\
\hline & gl & & & & & 47 & & & 3 & 3 & \\
\hline \multirow[t]{2}{*}{ H.wrightii } & $\mathbf{P}$ & & & & & 0.322 & & & 0.013 & 0.570 & \\
\hline & critical value & & & & & $\mathrm{F}=1.37$ & & & $F=9.89$ & $\mathrm{~F}=0.62$ & \\
\hline
\end{tabular}




\section{Table 4(on next page)}

\section{Macroalgae coverage}

Summary of macroalgae coverage (\%) measured in LPBR at different water depths(1-5 m depth), showing mean $\pm S D$, median, minimum and maximum values. 


\begin{tabular}{lllll}
\hline $\begin{array}{l}\text { Depth } \\
(\mathrm{m})\end{array}$ & $\begin{array}{c}\text { Macroalgae } \\
\text { coverage } \\
(\%)\end{array}$ & Min & Max & Median \\
\hline 1 & $39 \pm 16$ & 20 & 55 & 40 \\
2 & $29 \pm 16$ & 10 & 50 & 30 \\
3 & $16 \pm 10$ & 5 & 40 & 10 \\
4 & $15 \pm 6$ & 10 & 20 & 15 \\
5 & $27 \pm 18$ & 15 & 40 & 27.5 \\
\hline
\end{tabular}

1 


\section{Table 5 (on next page)}

Carbon stores in aerial and belowground biomass

Carbon stores in aerial and belowground biomass. Net organic and inorganic carbon storage and at $1 \mathrm{~m}$ in sediment, showing mean \pm SD. 


\begin{tabular}{cllll}
\hline $\begin{array}{c}\text { Depth } \\
(\mathrm{m})\end{array}$ & $\begin{array}{c}\text { Aboveground } \\
\text { and } \\
\text { belowground } \\
\mathrm{Mg} \mathrm{C} \mathrm{ha}^{-1}\end{array}$ & $\begin{array}{c}\text { Sediment } \\
\mathrm{Mg} \mathrm{C} \mathrm{ha}^{-1} \\
\mathrm{Net}\end{array}$ & $\begin{array}{c}\text { Sediment } \\
\mathrm{Mg} \mathrm{C} \mathrm{ha}^{-1} \\
\text { Top 1 m }\end{array}$ & $\begin{array}{c}\text { Sediment } \\
\mathrm{Mg} \mathrm{Cing} \mathrm{ha}^{-1} \\
\text { Top 1 m }\end{array}$ \\
\hline 1 & $3.1 \pm 1.7$ & $249 \pm 183$ & $463 \pm 267$ & $131 \pm 119$ \\
2 & $3.7 \pm 2.3$ & $147 \pm 137$ & $329 \pm 225$ & $130 \pm 103$ \\
3 & $1.8 \pm 1.1$ & $103 \pm 50$ & $301 \pm 184$ & $135 \pm 85$ \\
4 & $1.9 \pm 1.3$ & $96 \pm 76$ & $271 \pm 230$ & $129 \pm 122$ \\
5 & $1.1 \pm 0.9$ & $77 \pm 42$ & $229 \pm 207$ & $125 \pm 122$ \\
\hline
\end{tabular}

8 
Table 6(on next page)

Carbon stoks by seagrass classes

Carbon stoks by seagrass classes, total biomass and sediment top $1 \mathrm{~m}$, showing mean $\pm \mathrm{SD}$. Ecosytem carbon stock and $\mathrm{CO} 2$ euivalences in LPBR. 
1

2

3

4

5

6

7

8

\begin{tabular}{ccclll}
\hline Class & $\begin{array}{c}\text { Extension } \\
\text { (ha) }\end{array}$ & $\begin{array}{c}\text { Biomass Mg } \\
\mathrm{C} \mathrm{ha}^{-1}\end{array}$ & $\begin{array}{l}\text { Sediment } \\
\mathrm{Mg} \mathrm{C} \mathrm{ha}^{-1} \\
\text { top 1 m }\end{array}$ & $\begin{array}{l}\text { Ecosystem } \\
\text { carbon } \\
\text { stock Tg C }\end{array}$ & $\begin{array}{l}\text { Ecosystem } \\
\text { carbon } \\
\text { stock } \\
\mathrm{TgCO}_{2 \mathrm{eq}}\end{array}$ \\
\hline MxMa & 51,884 & $2.7 \pm 1.90$ & $307 \pm 185$ & 16 & 59 \\
MxSf & 44,492 & $0.82 \pm 0.60$ & $315 \pm 299$ & 14 & 51 \\
TtMa & 30,189 & $2.66 \pm 1.55$ & $411 \pm 226$ & 13 & 48 \\
SfTt & 23,048 & $1.76 \pm 0.98$ & $155 \pm 98$ & 4 & 15 \\
TOTAL & $\mathbf{1 4 9 , 6 1 3}$ & & & $\mathbf{4 7}$ & $\mathbf{1 7 3}$ \\
\hline
\end{tabular}

9 


\section{Table 7 (on next page)}

$\delta 13 \mathrm{C}$ and $\delta 15 \mathrm{~N}$ values of seagrass sediments

Mean \pm SD $\delta 13 C$ and $\delta 15 \mathrm{~N}$ values of seagrass sediments, proportional contribution by each source to seagrass in LPBR at different water depths(1-5 m water depth). 


\begin{tabular}{ccclllll}
\hline $\begin{array}{c}\text { Depth } \\
(\mathbf{m})\end{array}$ & $\boldsymbol{\delta}^{\mathbf{1 3}} \mathbf{C}$ & $\boldsymbol{\delta}^{\mathbf{1 5}} \mathbf{N}$ & $\begin{array}{l}\mathbf{B D} \\
\left(\mathbf{g} \mathbf{~ c m}^{-3}\right)\end{array}$ & $\begin{array}{l}\mathbf{O M} \\
\mathbf{( \% )}\end{array}$ & Seagrass & Macroalgae Mangrove \\
\hline 1 & & & & & & \\
Mean \pm SD & $-21 \pm 4.2$ & $3 \pm 2$ & $0.2 \pm 0.2$ & $26 \pm 9$ & $0.50 \pm 0.25$ & $0.38 \pm 0.25$ & $0.10 \pm 0.07$ \\
Median & -21 & 4 & 0.23 & 25.94 & & & \\
Min-Max & $-24--14$ & $1-6$ & $0.12-0.6$ & $12-36$ & & & \\
2 & & & & & & & \\
Mean \pm SD & $-17 \pm 3.7$ & $4 \pm 0.6$ & $0.2 \pm 0.1$ & $35 \pm 19$ & $0.53 \pm 0.26$ & $0.37 \pm 0.26$ & $0.09 \pm 0.06$ \\
Median & -19 & 4 & 0.25 & 31 & & & \\
Min-Max & $-19--11$ & $3-5$ & $0.04-0.3$ & $17-57$ & & & \\
3 & & & & & & & \\
Mean \pm SD & $-16 \pm 1.9$ & $3 \pm 1$ & $0.5 \pm 0.2$ & $15 \pm 5$ & $0.59 \pm 0.26$ & $0.32 \pm 0.25$ & $0.07 \pm 0.05$ \\
Median & -16 & 4 & 0.5 & 14 & & & \\
Min-Max & $-18--13$ & $1-4$ & $0.3-0.8$ & $10-22$ & & & \\
4 & & & & & & & \\
Mean \pm SD & $-16 \pm 0.4$ & $3 \pm 0.6$ & $0.2 \pm 0.07$ & $12 \pm 5$ & $0.59 \pm 0.26$ & $0.33 \pm 0.07$ & $0.07 \pm 0.05$ \\
Median & -16 & 3 & 0.2 & 9 & & & \\
Min-Max & $-17--16$ & $3-4$ & $0.08-0.2$ & $7-17$ & & & \\
5 & & & & & & & \\
Mean \pm SD & $-14 \pm 1$ & $3 \pm 2$ & $0.3 \pm 0.1$ & $10 \pm 9$ & $0.62 \pm 0.25$ & $0.30 \pm 0.25$ & $0.06 \pm 0.04$ \\
Median & -14 & 3 & 0.3 & 7 & & & \\
Min-Max & $-15--13$ & $0.2-4$ & $0.16-0.4$ & $5-28$ & & & \\
\hline
\end{tabular}

2

3

4

5 